

\section{Sumário}

EDITORIAL

Bruno Amaral Machado, Camilla de Magalhães Gomes e Soraia Mendes

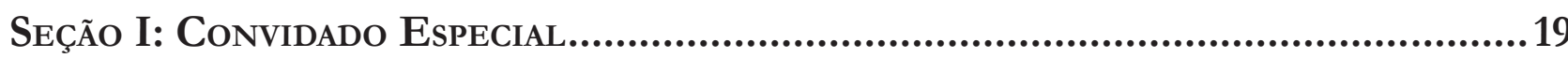

Autonomia Pessoal, Destino, julgamentos e instituições no Brasil: Notas Sobre uma PERGUNTA E ALGUMAS RESPOSTAS

Luiz Edson Fachin

SEÇÃo 2: Dossiê Temático....................................................................................40

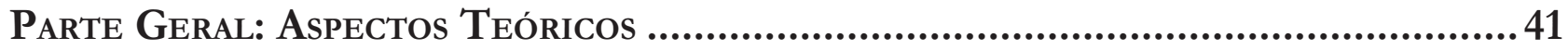

Raça e essencialismo na Teoria Feminista do Direito .......................................................43

Angela P. Harris, Tradução de Camilla de Magalhães Gomes e Ísis Aparecida Conceição

Políticas da morte: Covid-19 E Os Labirintos da Cidade Negra ........................................75

Ana Flauzina e Thula Pires

QUem PARIU AMÉFrica?: TRABALHO DOMÉSTICO, CONSTITUCIONALISMO E MEMÓRIA EM PRETUGUÊS

Juliana Araújo Lopes

O Lixo Vai Falar: Racismo, Sexismo e Invisibilidades do Sujeito Negro nas Narrativas de Direitos Humanos

Ciani Sueli das Neves

DiREITOS HUMANOS, DECOLONIALIDADE E FEMINISMO DECOLONIAL: FERRAMENTAS TEÓRICAS PARA A COMPREENSÃO DE RAÇA E GÊNERO NOS LOCAIS DE SUBALTERNIDADE

Rute Passos, Letícia Rocha Santos e Fran Espinoza

Direito, RAÇA E GÊNERO: ELEMENTOS PARA A CONSTRUÇÃo DE UMA TEORIA FEMINISTA DO DIREITO ADEQUADA AO FEMINISMO NEGRO

Mário Lúcio Garcez Calil e Debora Markman

"NeGras VAdiAs": A CRIMINALIZAÇÃo Do CORPO NEGRO QUE OUSA PROTESTAR.

Soraia da Rosa Mendes e Bruno Amaral Machado

A experiênCia do Abaetê Criolo como aÇão de enfrentamento a desigualdades de GÊNERO E RAÇA: UMA ANÁLISE DE DISCURSO SOBRE INTERSECCIONALIDADE

E FEMINISMO NEGRO

David Oliveira e Thalita Terto Costa 
ENTRE A AUSÊNCIA E O EXCESSO: A ATUAÇÃo DO ESTADO SOBRE CORPOS DISSIDENTES 230 Dayane do Carmo Barretos, Klelia Canabrava Aleixo e Vanessa de Sousa Soares

SILÊNCIOS E MITOS NUMA PERSPECTIVA INTERSECCIONAL: DO CONTROLE INFORMAL DE CORPOS AO CONTROLE PENAL DE MULHERES NEGRAS ......................................................248 Elaine Pimentel e Nathália Wanderley

Ministério Público e domínio Racial: poucas ilhas negras EM UM ARQuipélago nãoNEGRO 267

Saulo Murilo de Oliveira Mattos

Políticas públicas Para a ARTiCulaÇão de GÊNERo E RAÇA: MEIOS PARA GARANTir A REPRESENTATIVIDADE POLÍtiCA E JURÍDiCA DA MULHER NEGRA NO BRASIL 296 Mariana Dionísio de Andrade e Eduardo Régis Girão de Castro Pinto

Parte Específica: Incidências Concretas.......................................................... 317

REIMAGING THE POLICING OF GENDER VIOLENCE: LESSONS FROM WOMEN'S POLICE STATIONS IN Brasil AND ArgENTINA............................................................................................ 319 Kerry Carrington, Melissa Bull, Gisella Lopes Gomes Pinto Ferreira e María Victoria Puyol

NECROBIOPOLIÍtica DE GÊNERo No BRASIL CONTEMPORÂNEO: O FEMINICÍDIO EM TEMPOS DE FASCISMO SOCIAL 340 Maiquel Ângelo Dezordi Wermuth e Joice Graciele Nielsson

ViolÊNCIA CONTRA MULHERES QUILOMBOLAS: UMA REFLEXÃo SOBRE A APLICAÇÃo DE UMA PERSPECTIVA INTERSECCIONAL À LUZ DA IDEIA DE CONTRAPÚBLICOS SUBALTERNOS DELINEADA POR FRASER..... 360 Maria Eugenia Bunchaft, Leonardo Rabelo de Matos Silva e Gustavo Proença da Silva Mendonça

Políticas públicas de PREVEnÇÃo aO Feminicídio E INTERSECCIONALIDAdes . 384 Thiago Pierobom de Ávila, Marcela Novais Medeiros, Cátia Betânia Chagas, Elaine Novaes Vieira, Thais Quezado Soares Magalhães e Andrea Simoni de Zappa Passeto

DiREITO DE VIVER SEM VIOLÊNCIA: PROTEÇÃO E DESAFIOS DOS DIREITOS DAS MULHERES indígenas no Sistema InTERAmericano de Direitos Humanos Julia Natália Araújo Santos e Felipe Rodolfo de Carvalho

ANÁlise de GÊNERo E DE CRUZAMENTOS INTERSECCIONAIS DE UM PROGRAMA PARA AUTORES DE VIOLÊNCIA DOMÉSTICA CONTRA AS MULHERES

Mariana Fernandes Távora, Dália Costa, Camilla de Magalhães Gomes e Adriano Beiras

Controle PENAL dA LOUCURA E DO GÊNERO: REFLEXÕES INTERSECCIONAIS SOBRE MULHERES EgRESSAS DA MEdidA DE SEgurANÇA No Rio DE JANEIRO. .468 Bruna Martins Costa e Luciana Boiteux 
ONDE ESTÃo NOSSOS DIREITOS? O CAMPO FEMINISTA DE GÊNERO BORDADO PELAS MULHERES ATINGIDAS POR BARRAGENS

Tchenna Fernandes Maso e Tchella Fernandes Maso

Os SEGREDOS EPISTÊMICOS DO DIREITO DO TRABALHO.

Flávia Souza Máximo Pereira e Pedro Augusto Gravatá Nicoli

Reforma trabalhista e desigualdade de GÊNERo no Brasil: uMa PERSPECTIVA JuRÍdicA E ECONÔMICA

Natalia Branco Lopes Krawczun, Magno Rogério Gomes e Solange de Cassia Inforzato de Souza

A COLONIALIDADE DO PODER NA PERSPECTIVA DA INTERSECCIONALIDADE DE RAÇA E GÊNERO: ANÁLISE DO CASO DAS EMPREGADAS DOMÉSTICAS NO BRASIL .565

Daphne de Emílio Circunde Vieira Andrade e Maria Cecília Máximo Teodoro

COMPETIÇÃO POLÍTICA E DESIGUALDADES DE GÊNERO NAS ELEIÇÕES PARA ASSEMBLEIAS ESTADUAIS EM 2018

Lígia Fabris Campos, Décio Vieira da Rocha, Leandro Molhano Ribeiro e Vitor Peixoto

DisCrit: os LIMITES DA INTERSECCIONALIDADE PARA PENSAR SOBRE A PESSOA NEGRA COM DEFICIÊNCIA

Philippe Oliveira de Almeida e Luana Adriano Araújo

SeÇão III: Temais GeraIS

La Corte Interamericana de Derechos Humanos. Hermenéutica del derecho al MEDIO AMBIENTE SANO, A LA IDENTIDAD CULTURAL Y A LA CONSULTA, A LA LUZ DE LA SENTENCIA “Lhaka Honhat (nUestra tierra) vs. Argentina” (2020)

Juan Jorge Faundes Peñafiel, Cristobal Carmona Caldera e Pedro Pablo Silva Sánchez

LA RESPUESTA INSTITUCIONAL FRENTE A LA TRATA DE PERSONAS EN EL ESTADO DE CHIHUAHUA.

UN ANÁLISIS DE POLÍTICA PÚBLICA .676 Martha Aurelia Dena Ornelas

Comunidades quilombolas, RaCismo e ideologia no discurso de JAIr Bolsonaro: estudo CRÍTICO DOS DISCURSOS POLÍTICO E JUDICIAL 700 Ricardo de Macedo Menna Barreto e Helena Mascarenhas Ferraz

O Princípio Geral da Boa Administração no Código do Procedimento Administrativo Português. Pistas de inVestigação. 724 Ana Melro 


\title{
Quem pariu Améfrica?: trabalho doméstico, constitucionalismo e memória em pretuguês*
}

\section{Who gave birth to Améfrica: domestic labor, constitutionalism and memory in pretuguês}

\author{
Juliana Araújo Lopes**
}

\section{Resumo}

Este artigo revisita o debate constitucional sobre história e memória nacional no discurso dos juristas a partir da categoria político-cultural de amefricanidade, cunhada por Lélia Gonzalez, entendendo o trabalho reprodutivo como aspecto central do mito da democracia racial. Trago para o centro do debate as lutas por direitos do movimento associativo/sindical de trabalhadoras domésticas no Brasil a partir da atuação na Assembleia Nacional Constituinte de 1987/1988, marcada pelo silenciamento de suas demandas por serem consideradas "como se fossem da família". Essa experiência chama atenção para a relação entre direitos fundamentais e imagens de controle, articuladas em torno da degeneração da sexualidade e da maternidade de mulheres negras. Entre a casa grande e a senzala, a família constitui o espaço de disputa do papel das mulheres-emblema da harmonia entre as raças na democracia, ao mesmo tempo dentro e fora dela. A partir da tensão entre imagem e linguagem apresentada por Gonzalez, compreendendo a mãe preta como a mãe na cultura brasileira, o pretuguês revela a amefricanidade denegada; possibilitando o reconhecimento e a reparação dos traumas da escravidão presentes no constitucionalismo brasileiro a partir da agência política das trabalhadoras domésticas. A ancestralidade aponta o caminho para reorientar nosso projeto democrático.

Palavras-chave: Constitucionalismo brasileiro. Trabalhadoras domésticas. Amefricanidade. Feminismo Negro. Ancestralidade.

\section{Abstract}

This article revisits the debate on national history and memory in the discourses of jurists from the political-cultural category of amefricanity, comprehending reproductive labor as key to the myth of racial democracy. Bringing the contributions the struggles for rights of the associative/unionized domestic workers movement in Brazil, starting by their participation at the National Constituent Assembly of 1997/1998, marked by the silencing of their demands for being considered "like one of the family". This experience draws attention to the link between fundamental rights and controlling images, articulated around the degeneration of black women's sexuality and maternity. In between casa grande and senzala, the family is the space of dispute over the roles of the women who are symbols of racial harmony in

** Doutoranda em Direito, Estado e Constituição no PPGD/UnB.

E-mail: julianaaraujolopes2@gmail.com
* Recebido em 30/05/2020 Aprovado em 02/07/2020 
democracy, simultaneously as in and outsiders. From the tension between image and language presented by Lélia Gonzalez, comprehending the mãe preta as the mother in Brazilian culture, pretuguês reveals the denied amefricanity; allowing recognition and reparation of the traumas of colonialism present in democracy, from the political agency of domestic workers. Ancestrality points the direction to rethink our democratic project.

Keywords: Brazilian Constitutionalism. Domestic Workers. Amefricanity. Black Feminism. Ancestrality.

\section{Introdução}

"Para criarmos uma nação, temos que criar o impulso comum de projeto com relação ao futuro. E para podermos ter impulso em relação ao futuro, temos de conhecer o nosso passado." Lélia Gonzalez.

Falar de trabalho doméstico e constitucionalismo no Brasil de 2020 levanta mais perguntas que respostas. A indignação do ministro da economia com a doméstica que viaja para a Disney como baliza de austeridade econômica; o registro da primeira morte por COVID-19 no país, de uma trabalhadora doméstica idosa no Rio de Janeiro, contaminada na casa dos empregadores que retornavam de uma viagem à Europa; e a trágica morte do menino Miguel, que despencou do alto de um edifício de luxo em Recife, enquanto, em plena pandemia, sua mãe passeava com o cachorro da patroa, esposa do prefeito corrupto, que estava ocupada fazendo as unhas; certamente dizem muito sobre o contexto que vivemos.

A credibilidade da Constituição, da Suprema Corte e das instituições jurídicas em geral não tem estado lá muito em alta. Fascismo, genocídio e necropolítica passaram a compor a constelação de palavras da ordem do dia para descrever a sucessão de barbaridades do governo federal, enquanto protestos contra o racismo eclodem por todo o mundo, já que a polícia compete com o vírus para ver quem mata mais. Estátuas de colonizadores, senhores de escravos e confederados são derrubadas quando mais um homem negro vai ao chão sem conseguir respirar. Se estamos ou não num momento de inflexão da história, só o futuro vai dizer. Mas ecoa a pergunta feita por Lélia Gonzalez mais de 30 anos atrás. "E aí? Cumé que a gente fica?”

A pergunta inscreve um duplo movimento. Primeiro, sobre o lugar do emprego doméstico nas crises do nosso tempo, e, segundo, sobre o lugar das contribuições de intelectuais negras nas leituras sobre elas e na formulação de estratégias para combatê-las. Recorro a Patricia Hill Collins para dizer que, assim como as trabalhadoras domésticas são "quase da família", as outsiders internas que observam o funcionamento da supremacia branca de perto nas casas grandes, que, definitivamente, não fazem parte da família (senão receberiam herança); as mulheres negras acadêmicas são "quase intelectuais", ao mesmo tempo dentro e fora da universidade e de outras instituições, que não gozam da legitimidade dos brancos, mesmo que tenham os mesmos títulos ${ }^{2}$. Arrisco dizer que, aqui da margem, aprendemos uma coisa ou outra sobre esse barato chamado democracia que vale a pena escutar.

O linguajar coloquial de Lélia pode soar estranho num texto acadêmico, mas é o marcador epistêmico que aproxima os critérios de validação das duas comunidades a que atendem essas intelectuais: a comunidade de seus pares científicos, orientada pelo pensamento ocidental hegemônico dentro das instituições de ensino superior, e suas comunidades de origem, compostas majoritariamente por mulheres sem acesso à educação formal, mas que produziram uma teoria crítica social a partir do que Collins chamou de dialética

GONZALEZ, Lélia. Racismo e sexismo na cultura brasileira. Revista Ciências Sociais Hoje - Anpocs, p. 223-244, 1984. p. 223.

2 COLLINS, Patrícia Hill. Pensamento feminista negro: conhecimento, consciência e a política do empoderamento. São Paulo: Boitempo, 2019. 
entre opressão e ativismo, uma sabedoria coletiva oposicional à supremacia branca e masculina ${ }^{3}$. Essa tensão reflete impactos da presença negra nas universidades, intensificada pelas ações afirmativas desde os anos 2000.

A escolha de escrever em pretuguês, em vez de juridiquês, carrega os riscos de assumir o ato da fala com todas as suas implicações. O pretuguês designa marcas de africanização nos idiomas coloniais, presentes também na música, no sistema de crenças e nas histórias de luta silenciadas. Em termos constitucionais, enquanto evidência da africanidade viva na formação histórico-cultural do continente, denegada pela neurose do racismo, desafia os marcos tradicionais de fundação do Estado-nação. Nesse sentido, não seríamos uma América Latina, continuidade da Europa ibérica nos trópicos, progressivamente embranquecida pela miscigenação, mas uma América Africana, ou Améfrica Ladina. A linguagem guarda inscrições de uma história que não foi escrita, reveladas pelas mancadas do discurso jurídico. Então, como diria Lélia, "o lixo vai falar”. O silêncio nunca nos protegeu ${ }^{5}$.

Seguindo a trilha da linhagem de intelectuais negras que me precederam, elejo o pensamento da antropóloga Lélia de Almeida Gonzalez (1935-1994) como mapa analítico do percurso da trajetória política do movimento de trabalhadoras domésticas, hoje organizado no Brasil na forma da FENATRAD - Federação Nacional das Trabalhadoras Domésticas. Fazendo coro a Raquel Barreto, que restitui Lélia Gonzalez ao lugar de intérprete da nação $0^{6}$, e a Thula Pires, que, há alguns anos, mobiliza esforços para a construção de um constitucionalismo ladinoamefricano ${ }^{7}$, este artigo revisita o debate constitucional sobre história e memória nacional no discurso dos juristas ${ }^{8}$ a partir da categoria político-cultural de amefricanidade, cunhada por Lélia, entendendo o trabalho reprodutivo como aspecto central do mito da democracia racial ${ }^{9}$.

Trago para o centro do debate as lutas por direitos do movimento associativo/sindical de trabalhadoras domésticas no Brasil a partir de sua atuação na Assembleia Nacional Constituinte - ANC de 1987/1988, marcada pelo silenciamento de suas demandas por serem consideradas "como se fossem da família" experiência chama atenção para a relação entre direitos fundamentais e imagens de controle, articuladas em torno da degeneração da sexualidade e da maternidade de mulheres negras ${ }^{11}$. Fala, ainda, das permanências da escravidão no nosso presente. Para além de um sistema político e econômico, a escravidão é entendida como um trauma, uma ferida que nunca foi tratada ${ }^{12}$.

O texto se organiza em cinco partes: a primeira faz apontamentos iniciais sobre a participação das trabalhadoras na ANC e os limites que o ordenamento constitucional de 1988 apresenta em termos de raça, gênero e classe. A segunda revisita o debate sobre história e memória nacional nos discursos dos juristas, identificando a relação entre o mito da democracia racial e as lutas das trabalhadoras domésticas. Na terceira, tento responder à pergunta do título: "Quem pariu Améfrica?”, relacionando a trajetória de regulação do

3 COLLINS, Patrícia Hill. Pensamento feminista negro: conhecimento, consciência e a política do empoderamento. São Paulo: Boitempo, 2019.

${ }_{4}$ GONZALEZ, Lélia. Racismo e sexismo na cultura brasileira. Revista Ciências Sociais Hoje - Anpocs, p. 223-244, 1984.

5 LORDE, Audre. A transformação do silêncio em linguagem e ação. In: LORDE, Audre. Irmã outsider: ensaios e conferências. Belo Horizonte: Autêntica Editora, 2019.

6 BARRETO, Raquel. Lélia Gonzalez: uma intérprete do Brasil. In: GONZALEZ, Lélia. Primavera para as rosas negras: Lélia Gonzalez em primeira pessoa. São Paulo: Diáspora Africana, 2018.

PIRES, Thula. Por um constitucionalismo ladinoamefricano. In: BERNARDINO-COSTA, Joaze; MALDONADO-TORRES, Nelson; GROSGOGUEL, Ramon (orgs.). Decolonialidade e pensamento afrodiaspórico. Belo Horizonte: Autêntica Editora, 2018.

8 DUARTE, Evandro Piza; SCOTTI, Guilherme. História e memória nacional no discurso jurídico: o julgamento da ADPF 186. Universitas JUS, Brasília, v. 24, n. 3, p. 33-45, 2013. Disponível em: https://www.publicacoesacademicas.uniceub.br/jus/article/ view/2611 Acesso em: 15 ago. 2019.

9 GONZALEZ, Lélia. Racismo e sexismo na cultura brasileira. Revista Ciências Sociais Hoje - Anpocs, p. 223-244, 1984.

10 RAMOS, Gabriela Batista Pires. "Como se fosse da família”: o trabalho doméstico na Assembleia Nacional Constituinte de 1987/1988. Dissertação (Mestrado em Direito) - Universidade Federal da Bahia, Salvador, 2018.

11 COLLINS, Patrícia Hill. Pensamento feminista negro: conhecimento, consciência e a política do empoderamento. São Paulo: Boitempo, 2019.

12 KILOMBA, Grada. Memórias da Plantação: episódios de racismo cotidiano. Rio de Janeiro: Cobogó, 2019. 
emprego doméstico com o controle reprodutivo de mulheres negras. Na quarta, falo de amefricanidade, maternidade e memória. A mãe preta é a mãe na cultura brasileira. Quais as implicações disso? Indico uma relação entre amefricanidade, constitucionalismo e ancestralidade. Na quinta e última parte, trago o pensamento feminista negro e as imagens de controle como possibilidades para o Direito, que nos provocam a alargar nossas concepções de direitos fundamentais.

\section{Constitucionalização do emprego doméstico na democracia genocida}

Sou Lenira, empregada doméstica, sou do Recife e estou aqui com as companheiras de todo o Brasil. Digo as companheiras que aqui estão que temos que aproveitar esta oportunidade de falar para os poucos Constituintes presentes que temos consciência de que eles aqui estão, porque o povo aqui os colocou. É por isso que vimos, hoje, cobrar, como todos os trabalhadores estão cobrando, porque nós, domésticas, também votamos. Trabalhamos e fazemos parte deste País, muito embora não queiram reconhecer o nosso trabalho, porque não rendemos e não produzimos. Mas, estamos conscientes de que produzimos e produzimos muito. E achamos que, numa hora em que há uma Constituinte, uma nova Constituição para fazer, acreditamos, temos a esperança de que vamos fazer parte dessa Constituição. Não acreditamos que façam uma nova Constituição sem que seja reconhecido o direito de 3 milhões de trabalhadores deste País. Se isso acontecer, achamos que, no Brasil, não há nada de democracia, porque deixam milhares de mulheres no esquecimento ${ }^{13}$.

A Constituição Federal de 1988 foi a primeira do ordenamento jurídico brasileiro a reconhecer textualmente as trabalhadoras domésticas como categoria laboral, uma conquista que se deveu à mobilização expressiva de associações de trabalhadoras por todo o país, como um dos diversos movimentos sociais que viram na redemocratização uma oportunidade de disputa ${ }^{14}$.

Caracterizada pela interseccionalidade, a organização política das trabalhadoras domésticas brasileiras, ao longo de seus mais de 80 anos de história ${ }^{15}$, estabeleceu interlocuções sobretudo com os movimentos negro, feminista e sindical ${ }^{16}$. Tendo como porta-voz e principal parceira a deputada federal Benedita da Silva (PT/ $\mathrm{RJ})^{17}$, levaram à Assembleia Nacional Constituinte uma carta contendo as seguintes demandas: o reconhecimento como categoria profissional; a equiparação de direitos trabalhistas e previdenciários aos dos demais trabalhadores; o direito à sindicalização; além da proibição do trabalho infantil à pretexto de criação e educação ${ }^{18}$.

13 BRASIL. Senado Federal. Atas da Subcomissão dos Direitos dos Trabalbadores e Servidores Públicos. Brasília: Senado Federal, 1987. Disponível em: https://www.senado.leg.br/publicacoes/anais/asp/CT_Abertura.asp. Acesso em: 01 dez. 2019.

14 RAMOS, Gabriela Batista Pires. "Como se fosse da família": o trabalho doméstico na Assembleia Nacional Constituinte de 1987/1988. Dissertação (Mestrado em Direito) - Universidade Federal da Bahia, Salvador, 2018.

15 Por mais de 50 anos, a categoria das trabalhadoras domésticas se reuniu apenas na forma de associações de caráter beneficente ou profissional. Elas somente teriam direito à sindicalização após a promulgação da Constituição Federal em 5 de outubro de 1988 , embora o início sua organização política coletiva date de 1936, quando Laudelina de Campos Mello fundou a primeira associação de trabalhadoras domésticas do país em Santos/SP como um departamento da Frente Negra Brasileira. PINTO, Elisabete Aparecida. Etnicidade, gênero e educaşão: trajetória de vida de Laudelina de Campos Mello. São Paulo: Anita Garibaldi, 2015.

16 BERNARDINO-COSTA, Joaze. Sindicatos das trabalhadoras domésticas no Brasil: teorias de descolonização e saberes subalternos. 2007. Tese (Doutorado em Sociologia) - Universidade de Brasília, Brasília, 2007.

17 Benedita da Silva, a única mulher negra eleita entre os mais de 500 parlamentares constituintes, foi escolhida como representante e porta voz da categoria no processo constituinte. Ela participava ativamente das atividades de articulação regional e nacional das trabalhadoras domésticas desde o início da década de 1980, ainda como vereadora no Rio de Janeiro, atuando junto às igrejas católicas que por muito tempo abriram espaço para as associações, e traçando linhas de atuação conjuntas para incidência sobre a ANC. Destaca-se a presença de Benedita no V Congresso Nacional das Trabalhadoras Domésticas, realizado em 1985 em Nova Iguaçu/ RJ, onde se tiraram as diretrizes de atuação na Constituinte e onde se elaborou a carta acima referida, que seria levada à Subcomissão dos Direitos dos Trabalhadores e Servidores Públicos. Vale lembrar que a deputada e assistente social, que se definia como "mulher negra e favelada", já foi trabalhadora doméstica. BERNARDINO-COSTA, Joaze. Sindicatos das trabalhadoras domésticas no Brasil: teorias de descolonização e saberes subalternos. 2007. Tese (Doutorado em Sociologia) - Universidade de Brasília, Brasília, 2007. RAMOS, Gabriela Batista Pires. "Como se fosse da família”: o trabalho doméstico na Assembleia Nacional Constituinte de 1987/1988. Dissertação (Mestrado em Direito) - Universidade Federal da Bahia, Salvador, 2018.

18 BRASIL. Senado Federal. Atas da Subcomissão dos Direitos dos Trabalhadores e Servidores Públicos. Brasília: Senado Federal, 1987. 
Reivindicando sua condição de cidadãs e trabalhadoras, a maior categoria de mulheres que trabalham no Brasil, que então reunia cerca de $1 / 4$ (um quarto) de toda a mão de obra feminina nacional, contestava a definição jurídica do trabalho doméstico como serviço de natureza/finalidade não econômica ou não lucrativa.

Fala-se muito que os trabalhadores empregados domésticos não produzem lucro, como se fosse algo que se expressasse, apenas e tão-somente, em forma monetária. Nós, produzimos saúde, limpeza, boa alimentação e segurança para milhões de pessoas. Nós, que sem ter acesso instrução e cultura, em muitos e muitos casos, garantimos a educação dos filhos dos patrões ${ }^{19}$.

A figura da família está no centro da legislação que disciplina o emprego doméstico no Brasil ${ }^{20}$, e esteve também no centro das disputas sobre o tema durante a ANC. Embora tenha sido manejada estrategicamente por Benedita da Silva para sensibilizar e obter apoio de seus pares, a família foi evocada em geral por parlamentares constituintes que descreviam suas próprias empregadas "como se fossem da família", a partir de uma narrativa de afeto, benevolência e proteção do espaço privado, que teve como efeito a negação de suas demandas por igualdade e profissionalização ${ }^{21}$.

O senador Mansueto de Lavor (PMDB/PE), manifestando apoio às “ajudantes do lar", destacando sua importância para o equilíbrio e a formação da família brasileira, faz um testemunho pessoal em homenagem a Miralva, sua empregada, que já pertencia à família. O deputado Mário Lima (PMDB/BA), confessa que era dependente do trabalho de Maria, sua empregada, uma vez que era divorciado e a trabalhadora dirigia sua casa. Em seguida, declara:

A ajudante do lar, depois de certo tempo, passa a ser membro da família. Quem não tem na sua família, particularmente os nordestinos, aquela que viveu, ajudou nos afazeres da casa. [... É É importante que esses direitos não fiquem na base do coração, do reconhecimento, que isso seja lei para aquelas pessoas que não tenham essa formação cristã, essa sensibilidade, que a cumpram, não por sentimento, mas por obrigação ${ }^{22}$.

Por outro lado, as mulheres do movimento orientavam-se pela máxima: "não queremos ser da família, queremos direitos!”. Creuza Maria Oliveira conta sobre o encontro entre as trabalhadoras domésticas e o presidente da ANC, Ulysses Guimarães. "E Ulysses nos recebeu, e aí nos anais dele lá deve ter foto, a gente lá no plenário assim. E ele nos recebeu e fez aquele discurso lindo e maravilhoso -pra ele né"23. Tecendo elogios sobre a importância das trabalhadoras para a sociedade, o presidente diz que tinha uma empregada em sua casa há mais de 30 anos, que era como se fosse de sua família.

Disponível em: https://www.senado.leg.br/publicacoes/anais/asp/CT_Abertura.asp. Acesso em: 01 dez. 2019.

19 BRASIL. Senado Federal. Atas da Subcomissão dos Direitos dos Trabalbadores e Servidores Públicos. Brasília: Senado Federal, 1987. Disponível em: https://www.senado.leg.br/publicacoes/anais/asp/CT_Abertura.asp. Acesso em: 01 dez. 2019.

20 "Art. $7^{\circ}$ Os preceitos constantes da presente Consolidação salvo quando fôr em cada caso, expressamente determinado em contrário, não se aplicam: a) aos empregados domésticos, assim considerados, de um modo geral, os que prestam serviços de natureza não econômica à pessoa on à família, no âmbito residencial destas [grifo meu]". BRASIL. Decreto-Lei n. 5.452, de $1^{\circ}$ de maio de 1943. Aprova a Consolidação das Leis do Trabalho. Disponível em: http://www.planalto.gov.br/ccivil_03/decreto-lei/Del5452compilado.htm Acesso em: 7 out. 2020. No mesmo sentido, a Lei 5.859/72 assim definia o emprego doméstico: "Art. $1^{\circ}$ Ao empregado doméstico, assim considerado aquele que presta serviços de natureza contínua e de finalidade não lucrativa à pessoa ou à família no âmbito residencial destas, aplica-se o disposto nesta lei [grifo meu]". BRASIL. Lei n. 5.859 de 11 de dezembro de 1972. Dispõe sobre a profissão de empregado doméstico e dá outras providências. Disponível em: http://www.planalto.gov.br/ccivil_03/leis/L5859impressao.htm Acesso em: 7 out. 2020. A atual Lei Complementar 150, promulgada em junho de 2015, dispõe no mesmo sentido: "Art. 1. Ao empregado doméstico, assim considerado aquele que presta serviços de forma contínua, subordinada, onerosa e pessoal e de finalidade não lucrativa à pessoa ou à família, no âmbito residencial destas, por mais de 2 (dois) dias por semana, aplica-se o disposto nesta Lei [grifo meu]". BRASIL. Lei Complementar n. ${ }^{\circ} 150$, de $1^{\circ}$ de junho de 2015. Dispõe sobre o contrato de trabalho doméstico; altera as Leis nº 8.212 , de 24 de julho de 1991, no 8.213, [...]. Disponível em: https://www2.camara.leg.br/legin/fed/leicom/2015/leicomplementar-150-1-junho2015-780907-publicacaooriginal-147120-pl.html. Acesso em: 7 out. 2020.

21 RAMOS, Gabriela Batista Pires. "Como se fosse da família": o trabalho doméstico na Assembleia Nacional Constituinte de 1987/1988. Dissertação (Mestrado em Direito) - Universidade Federal da Bahia, Salvador, 2018.

22 BRASIL. Senado Federal. Atas da Subcomissão dos Direitos dos Trabalhadores e Servidores Públicos. Brasília: Senado Federal, 1987. Disponível em: https://www.senado.leg.br/publicacoes/anais/asp/CT_Abertura.asp. Acesso em: 01 dez. 2019.

23 OLIVEIRA, Creuza Maria. Entrevista concedida à autora. Brasília, 03 de dezembro de 2019. Em: LOPES, Juliana Araújo. Constitucionalismo brasileiro em pretuguês: trabalhadoras domésticas e lutas por direitos. 2020. Dissertação (Mestrado em Direito) - Universidade de Brasília, Brasília, 2020. 
E Lenira pegou... [...] Lenira hoje está com mais de 80 anos. Ai eu só sei que a gente nomeou Lenira pra falar e quando Lenira pegou o microfone, Lenira arrasou, né?!. Porque ela disse pra ele: "Nós não somos da família, nós somos trabalhadoras, fazemos parte da classe operária brasileira. E se o senhor reconhece a pessoa que trabalha na sua casa, não reconhece ela como família, mas reconhece ela enquanto uma trabalhadora. Então no dia que for aprovar aqui os direitos das domésticas, o senhor levante o crachá ao nosso favor. Ai o senhor vai estar realmente reconhecendo a pessoa que trabalha na sua casa." Foi lindo demais ${ }^{24}$.

A participação das trabalhadoras domésticas nos acampamentos, corredores, gabinetes e plenárias da ANC é um retrato ao mesmo tempo de uma abertura e de um fechamento para outros projetos de Brasil. Na Constituinte mais popular da história, elas foram barradas muitas vezes nas portas do Congresso Nacional. "O povo querendo entrar e os seguranças empurrando a gente pra fora" ${ }^{25}$. Mecanismos como as emendas populares foram inacessíveis para elas. $\mathrm{Na}$ Comissão de Sistematização, uma das fases finais do processo constituinte, convertida em um reduzido comitê político que fez cortes radicais nos temas debatidos por meses a fio pela sociedade civil, a maior parte de suas propostas foi removida ${ }^{26}$.

A redação final da Constituição reconheceu a categoria das trabalhadoras domésticas separadamente dos demais trabalhadores, na forma do parágrafo único do art. $7^{\circ}$, que estendeu a elas apenas nove do rol de 34 direitos fundamentais da ordem social do trabalho.

Entre os outros 25 direitos fundamentais que foram negados, estavam direitos das mulheres, obtidos a partir da inédita articulação da bancada feminina na ANC, importantes aliadas das domésticas no processo constituinte ${ }^{27}$. Estavam, ainda, uma série de dispositivos referentes à proteção à vida e à saúde do trabalhador, revelando uma dimensão necropolítica das normas constitucionais sobre o emprego doméstico ${ }^{2829}$, que remete às mortes preveníveis e evitáveis de mulheres negras no sistema de saúde ${ }^{30}$.

As normas que protegem o trabalhador de condições laborais análogas à escravidão foram igualmente afastadas para elas ${ }^{31}$. Compreende-se, nesse sentido, que a Constituição de 1988 forneceu, objetivamente, uma chancela constitucional para a prática do trabalho escravo na relação de emprego doméstico. Fixando uma determinada imagem sobre a categoria que mais reúne mulheres negras no país, o passado colonial esteve estranhamente presente nas bases do que seria o nosso Estado Democrático de Direito, 100 anos depois da abolição.

\footnotetext{
24 OLIVEIRA, 2018 apud RAMOS, Gabriela Batista Pires. "Como se fosse da família”: o trabalho doméstico na Assembleia Nacional Constituinte de 1987/1988. Dissertação (Mestrado em Direito) - Universidade Federal da Bahia, Salvador, 2018.

25 OLIVEIRA, Creuza Maria. Entrevista concedida à autora. Brasília, 03 de dezembro de 2019. Em: LOPES, Juliana Araujo. Constitucionalismo brasileiro em pretuguês: Trabalhadoras domésticas e lutas por direitos. No prelo, 2020.

26 RAMOS, Gabriela Batista Pires. "Como se fosse da família": o trabalho doméstico na Assembleia Nacional Constituinte de 1987/1988. Dissertação (Mestrado em Direito) - Universidade Federal da Bahia, Salvador, 2018.

27 OLIVEIRA, Adriana Vidal de. A constituição da mulher brasileira: uma análise dos estereótipos de gênero na Assembleia Constituinte de 1987-1988 e suas consequências no texto constitucional. 2012. Tese (Doutorado em Direito) - PUC-Rio, Rio de Janeiro, 2012.

28 Cunhado pelo filósofo camaronês Achille Mbembe, o conceito de necropolítica resgata a formulação foucaultiano do biopoder, que vincula soberania e poder de decisão sobre vida e morte, e sua articulação com a ideia de Estado de exceção, a partir da experiência colonial, removendo-as da sombra das experiências do nazismo, do totalitarismo e dos campos de extermínio. Em diálogo com Frantz Fanon, argumenta que a modernidade está na origem das práticas biopolíticas, que compõem o próprio tecido da democracia, que compatibiliza o discurso de liberdade e igualdade universal com a prática da escravidão, dos linchamentos e do encarceramento, entre outras expressões de racismo antinegro. A essa contradição e disjunção moral absoluta ele dá o nome de democracia de escravos. Essa lógica de produção de morte que determina a permanência da exceção se apoia sobre a contínua invenção de um outro, a imagem de um inimigo, que sustenta as chamadas políticas da inimizade. MBEMBE, Achille. Políticas da inimizade. Lisboa: Antígona, 2017.

29 RAMOS, Gabriela Batista Pires. "Como se fosse da família": o trabalho doméstico na Assembleia Nacional Constituinte de 1987/1988. Dissertação (Mestrado em Direito) - Universidade Federal da Bahia, Salvador, 2018.

30 CARNEIRO, Sueli. A construção do outro como não-ser como fundamento do ser. 2005. Tese (Doutorado em Educação) - Universidade de São Paulo, São Paulo, 2005.

31 RAMOS, Gabriela Batista Pires. "Como se fosse da família": o trabalho doméstico na Assembleia Nacional Constituinte de 1987/1988. Dissertação (Mestrado em Direito) - Universidade Federal da Bahia, Salvador, 2018.
} 
Longe de ser uma história de derrota das associações de trabalhadoras articuladas por todo o país, que lograram vitórias inéditas, a cena registra, antes, limites do próprio constitucionalismo a suas demandas. Se a democracia é compatível com o trabalho escravo, o que é, e para quem é, afinal, a democracia? ${ }^{32}$

"Como se fosse da família" aponta para uma relação entre família e escravidão que parece justificar a expressa negação de direitos fundamentais. Presente nas batalhas mais recentes do movimento, a exemplo da "PEC das domésticas" (PEC66/2012), da Emenda Constitucional 72 de 2013 e da Lei Complementar 150 de 2015, que a regulamenta, ela segue dando o tom da contínua luta por direitos e da persistente exclusão jurídica da categoria. Em entrevista ao portal Blogueiras Negras em 2013, Creuza Maria Oliveira afirmou:

O Senador presidente do Senado, Renan Calheiros, deu entrevista a nível nacional dizendo que naquele momento o Brasil estava assinando a sua segunda Lei Áurea, estava jogando a chave da senzala fora. Só que depois, no processo de regulamentação, [...] esqueceram que tinham assinado a segunda Lei Áurea [...]. Foram lá e pegaram a chave da senzala de volta e tornaram a nos trancar — querem nos trancar novamente na senzala ${ }^{33}$.

As décadas de 2000 e 2010, durante os governos Lula e Dilma, promoveram maior diálogo institucional no âmbito dos Poderes Legislativo e Executivo, o que viabilizou a criação deste novo conjunto normativo, ainda com muitos limites, sem que nunca logrem equiparação com os demais trabalhadores. " $\mathrm{N}]$ a verdade, a Lei 150 não equiparou de fato. Melhorou... [...] Então ficou lá muito tempo engavetado e tivemos muitas lutas pra chegar até aqui, que ainda não tá bom... não tá bom de jeito nenhum!’34.

Mais recentemente, a Reforma Trabalhista (Lei 13.467/2017), que fragilizou garantias constitucionais dos trabalhadores já no governo Michel Temer, pouco alterou as condições do emprego doméstico, já sistematicamente excluído desse arcabouço protetivo. "Quando a gente tava perto, aí eles tiraram das outras categorias. Entendeu?"35.

A Constituição inscreve o lugar das trabalhadoras domésticas nessa democracia genocida, cujas interdições sem ruptura têm como exceção mais a ampliação do alcance dos corpos que atinge do que a inovação de práticas autoritárias, que só importam quando se acirram a tal ponto que a água bate na bunda da branquitude ${ }^{36}$. Assentada sobre 520 anos "da história de um país que se consolidou na base não só dos açoites, mas também dos estupros, da dissolução dos laços familiares, da negação da infância como uma possibilidade e da velhice como um devir" ${ }^{37}$, a normalidade democrática oculta cenas de terror cotidiano nos quartinhos de empregada, verdadeiras senzalas modernas ${ }^{38}$.

$\mathrm{Na}$ festa da democracia, que disseram que era pra elas também, organizada por aquela galera gente fina, educada, viajada por esse mundo de Deus, que gosta muito de fazer discurso bonito dizendo o quanto o povo é oprimido, discriminado e explorado; elas não couberam na mesa e acabaram sentando lá no fundo. Se os donos da festa têm a chave da senzala, repetindo a mesma cena decadente há gerações, sem deixar de se surpreender quando seus próprios monstros saem do armário, talvez seja hora de armar uma quizumba ${ }^{39}$.

32 LOPES, Juliana Araújo. Constitucionalismo brasileiro em pretuguês: trabalhadoras domésticas e lutas por direitos. 2020. Dissertação (Mestrado em Direito) - Universidade de Brasília, Brasília, 2020.

33 BLOGUEIRAS NEGRAS. Creuza Oliveira em Mulheres na Conapir. 2013. 1 vídeo (47 min.) Disponível em: https://www.youtube. com/watch?v=CjG4zfPomoM. Acesso em: 30 jun. 2019.

34 RAMOS, Gabriela Batista Pires. "Como se fosse da família": o trabalho doméstico na Assembleia Nacional Constituinte de 1987/1988. Dissertação (Mestrado em Direito) - Universidade Federal da Bahia, Salvador, 2018. p. 146-149.

35 OLIVEIRA, Creuza Maria. Entrevista concedida à autora. Brasília, 03 de dezembro de 2019. Em: LOPES, Juliana Araújo. Constitucionalismo brasileiro em pretuguês: trabalhadoras domésticas e lutas por direitos. 2020. Dissertação (Mestrado em Direito) - Universidade de Brasília, Brasília, 2020.

36 FLAUZINA, Ana Luiza Pinheiro. Democracia genocida. In: PINHEIRO-MACHADO, Rosana; FREIXO, Adriano de (org.). Brasil em transe: Bolsonarismo, nova direita e desdemocratização. Rio de Janeiro: Oficina Raquel, 2019.

37 FLAUZINA, Ana Luiza Pinheiro. Democracia genocida. In: PINHEIRO-MACHADO, Rosana; FREIXO, Adriano de (org.). Brasil em transe: Bolsonarismo, nova direita e desdemocratização. Rio de Janeiro: Oficina Raquel, 2019. p. 63.

38 PRETA-RARA. Eu, empregada doméstica: a senzala moderna é o quartinho da empregada. Belo Horizonte: Letramento, 2019.

39 GONZALEZ, Lélia. Racismo e sexismo na cultura brasileira. Revista Ciências Sociais Hoje - Anpocs, p. 223-244, 1984. 
Porque, afinal, as ferramentas do senhor nunca derrubarão a casa grande ${ }^{40}$.

\section{Memória, história e democracia racial}

Beatriz Nascimento dizia que o corpo é o primeiro documento da travessia, o mapa do longo percurso que nos trouxe até aqui ${ }^{41}$. Em certo sentido, os caminhos migratórios das domésticas para trabalhar em casas de família atualizam as rotas da travessia atlântica, consumindo seus corpos para a reprodução de famílias brancas. As lutas negras por direitos falam "da recontagem dos feitos que divide o tabuleiro social entre vencedores e vencidos, arrojados e passivos, dominadores e dominados" ${ }^{42}$, da disputa das narrativas sobre eventos inscritos na superfície de nossas peles ${ }^{43}$. Compreendendo uma dimensão ancestral e coletiva da memória, a história importa para o constitucionalismo, porque é como o mundo secular atende aos mortos $^{44}$, de cuja existência somos o testemunho vivo ${ }^{45}$. É também o mapa para a construção de outros futuros possíveis, reorientados ${ }^{46}$.

As demandas por reconhecimento e redistribuição da população negra propõem construções sobre fatos no presente e no passado, acionando elementos historiográficos como recursos para interpretar a constituição das relações raciais no Brasil e as exclusões delas decorrentes ${ }^{47}$. Essas demandas frequentemente esbarram na retórica jurídica da "impossibilidade da memória", materializada pelo controverso episódio da queima dos arquivos da escravidão por Ruy Barbosa, ministro da fazenda quando da abolição ${ }^{48}$. Sem os documentos, seria impossível reparar os horrores coloniais, ou mesmo punir seus perpetradores.

Compreendendo o apagamento da memória da escravidão como elemento decisivo no padrão de negação de direitos à população negra, essa retórica registra a organização de arranjos jurídico-institucionais no período pós-abolição a partir de uma lógica de indenização dos senhores de escravos e suas famílias. Ao mesmo tempo em que se negam direitos aos negros, reitera-se um padrão de transmissão hereditária de privilégios políticos aos brancos, na forma da expropriação e constituição da propriedade privada ${ }^{49}$ (Pacto Agrário), da política fiscal favorável aos antigos senhores (Pacto Fiscal/Tributário) e da exclusão de amplos setores de direitos trabalhistas, repactuando novas formas de escravidão (Pacto Trabalhista) ${ }^{50}$.

40 LORDE, Audre. As ferramentas do senhor nunca derrubarão a casa grande. In: LORDE, Audre. Irmã outsider: ensaios e conferências. Belo Horizonte: Autêntica Editora, 2019.

41 NASCIMENTO, Beatriz. Beatriz Nascimento: quilombola e intelectual. São Paulo: Filhos da África, 2018.

42 FLAUZINA, Ana Luiza Pinheiro. Democracia genocida. In: PINHEIRO-MACHADO, Rosana; FREIXO, Adriano de (org.). Brasil em transe: Bolsonarismo, nova direita e desdemocratização. Rio de Janeiro: Oficina Raquel, 2019. p. 63.

43 KILOMBA, Grada. Memórias da Plantação: episódios de racismo cotidiano. Rio de Janeiro: Cobogó, 2019.

44 HARTMAN, Saidiya. Lose your mother: a journey along the Atlantic slave rout. New York: Farrar, Straus and Giroux, 2008.

45 GONZALEZ, Lélia. A categoria político-cultural de amefricanidade. Tempo Brasileiro, Rio de Janeiro, n. 92/93, p. 69-82, jan./ jun. 1988.

46 NASCIMENTO, Beatriz. Beatriz Nascimento: quilombola e intelectual. São Paulo: Filhos da África, 2018.

47 DUARTE, Evandro Piza; SCOTTI, Guilherme. História e memória nacional no discurso jurídico: o julgamento da ADPF 186. Universitas JUS, Brasília, v. 24, n. 3, p. 33-45, 2013. Disponível em: https://www.publicacoesacademicas.uniceub.br/jus/article/ view/2611 Acesso em: 15 ago. 2019.

48 DUARTE, Evandro Piza; SCOTTI, Guilherme; CARVALHO NETO, Menelick de. Ruy Barbosa e a queima dos arquivos: as lutas pela memória da escravidão e os discursos dos juristas. Universitas JUS, Brasília, v. 26, n. 2, p. 23-39, 2015. Disponível em: https:/ / www.publicacoesacademicas.uniceub.br/jus/article/view/3553 Acesso em: 23 abr. 2020.

49 Refere-se à política fundiária inaugurada pela Lei 601 de setembro de 1850, a chamada Lei de Terras, que alterou o regime de propriedade no Brasil, restringindo-o exclusivamente à compra, afastando a posse de fato. Este é um dos dispositivos implementados pelo Estado brasileiro como preparação para atender às transformações que viriam com a abolição em 1888, diante de um contexto internacional que pressionava pela extinção formal do regime escravista. Em face da futura e provável emancipação dos cativos, supunha-se que a ampla faixa de terras livres ou devolutas poderia vir a ser ocupada por eles, o que restringiria a força de trabalho disponível caso a abundância da terra não fosse restrita artificialmente. BERTÚLIO, Dora Lúcia de Lima. Direito e relações raciais: uma introdução crítica ao racismo. Rio de Janeiro: Lúmen Juris, 2019. p. 39.

50 DUARTE, Evandro Piza; SCOTTI, Guilherme; CARVALHO NETO, Menelick de. Ruy Barbosa e a queima dos arquivos: as lutas pela memória da escravidão e os discursos dos juristas. Universitas JUS, Brasília, v. 26, n. 2, p. 23-39, 2015. Disponível em: https:// 
O mito da democracia racial, articulado a partir da década de 1930 na obra de Gilberto Freyre ${ }^{51}$, confere ares de cientificidade ao mito das três raças, que orientou o discurso historiográfico oficial do país após a independência ${ }^{52}$. Apresentado como um modelo de integração das "raças inferiores" a partir da dupla mestiçagem biológica e cultural ${ }^{53}$, alternativo ao modelo segregacionista dos EUA, é marcado pelo caráter antidemocrático, antiliberal e conservador que sugere uma relação entre raça e memória nas ideologias nacionais latino-americanas, pautada pela ideia de harmonia, mas que opera como naturalização da violência, supressão da agência política e negação de cidadania que atravessa a experiência de negros e indígenas no Estado-nação ${ }^{54}$.

O mito se traduz, juridicamente, como a ideia de ausência de dispositivos racistas no ordenamento brasileiro, uma ideia que cai por terra quando analisada mais de perto. Dora Lúcia de Lima Bertúlio identifica um padrão de dispositivos normativos abertamente discriminatórios a partir da segunda metade do século XIX, que seguiriam produzindo efeitos ao longo do século XX. Operavam, sobretudo, em nível infraconstitucional ${ }^{55}$, na forma de contravenções penais e posturas municipais, normas de comportamento para proteção da moral, dos princípios e dos costumes da sociedade. Como forma de controle dos corpos no espaço da cidade, estratificavam racialmente a população. O controle penal e a exclusão de garantias trabalhistas informam sobre o lugar de abjeção e vigilância que se destinava à população negra com a proximidade da abolição ${ }^{56}$.

Fundado sobre o medo de que a população negra assumisse forma constitucional, também chamado de medo da "onda negra" ou do haitianismo, que moldou os conceitos de cidadania, liberdade, igualdade e nação desde a sua gênese ${ }^{57}$, o constitucionalismo brasileiro segue atualizando o espectro do Outro em imagens de pessoas negras, ao passo que segue também sendo disputado e desafiado pelas dinâmicas políticas da diáspora africana, por sujeitos que reinventam e denunciam os limites das promessas da modernidade ${ }^{58}$. Não se trata de uma memória impossível, mas da apropriação crítica dos vestígios das conexões do mundo atlântico.

O medo informa a construção do sujeito negro como inimigo para a segurança pública e para a segurança nacional, um dado que a Comissão Nacional da Verdade falhou em registrar. A denúncia da democracia racial, ideologia oficial do regime militar $^{59}$ e, de forma mais ampla, elemento de sustentação do pensamento autoritário brasileiro ${ }^{60}$, esteve no cerne das lutas do movimento negro contemporâneo, e orientou sua atuação na Assembleia Nacional Constituinte durante o processo de redemocratização.

A Constituição de 1988 inovou ao incorporar um rol significativo de dispositivos sobre a questão racial,

www.publicacoesacademicas.uniceub.br/jus/article/view/3553 Acesso em: 23 abr. 2020.

51 FREYRE, Gilberto. Casa grande \& senzala. Rio de Janeiro: Record, 2017.

52 VON MARTIUS, Karl Friedrich. Como se deve escrever a história do Brasil. Jornal do Instituto Histórico e Geográfico Brasileiro, Rio de Janeiro, n. 24, p. 401-402, jan. 1845.

53 MUNANGA, Kabengele. Rediscutindo a mestiçagem no Brasil. Belo Horizonte: Autentica Editora, 2004. p. 89.

54 DUARTE, Evandro Piza; SCOTTI, Guilherme; CARVALHO NETO, Menelick de. Ruy Barbosa e a queima dos arquivos: as lutas pela memória da escravidão e os discursos dos juristas. Universitas JUS, Brasília, v. 26, n. 2, p. 23-39, 2015. Disponível em: https:// www.publicacoesacademicas.uniceub.br/jus/article/view/3553 Acesso em: 23 abr. 2020.

55 A ênfase sobre normas infraconstitucionais não significa que não houvesse dispositivos constitucionais que refletissem valores racistas. Um dos exemplos emblemáticos é o art. 138 da Constituição de 1934, que determinava a incumbência da União, Estados e Municípios de estimular a educação eugênica, sinalizando que o branqueamento era entendido como política necessária para o desenvolvimento da nação brasileira. BERTÚLIO, Dora Lúcia de Lima. Direito e relações raciais: uma introdução crítica ao racismo. Rio de Janeiro: Lúmen Juris, 2019.

56 BERTÚLIO, Dora Lúcia de Lima. Direito e relações raciais: uma introdução crítica ao racismo. Rio de Janeiro: Lúmen Juris, 2019.

57 QUEIROZ, Marcos Vinícius Lustosa. Constitucionalismo brasileiro e o Atlântico Negro: a experiência constitucional de 1823 diante da Revolução Haitiana. Rio de Janeiro: Lúmen Juris, 2018.

58 GILROY, Paul. O Atlântico negro: modernidade e dupla consciência. São Paulo: Editora 34; Rio de Janeiro: Universidade Candido Mendes, Centro de Estudos Afro-Asiáticos, 2012.

59 PIRES, Thula Rafaela de Oliveira. Colorindo memórias e redefinindo olhares: ditadura militar e racismo no Rio de Janeiro. 2015. Disponível em: https://observatoriosc.org.br/noticia/colorindo-memorias-e-redefinindo-olhares-ditadura-militar-e-racismo-norio-de-janeiro/ Acesso em: 7 out. 2020.

60 MOURA, Clóvis. Sociologia do negro brasileiro. São Paulo: Ática, 1988. 
questionando o mito de integração ao reconhecer impactos da colonização no processo civilizatório do Brasil. Em face da resistência dos parlamentares constituintes a essa potente mobilização, acabou-se por ratificar o lugar das questões raciais na ordem constitucional da cultura ${ }^{61}$. O processo de constitucionalização do emprego doméstico, contudo, mostra que o mito operou largamente na ordem social do trabalho, indicando uma estreita relação entre escravidão, valores patriarcais e autoritarismo ${ }^{62}$. Qual o papel do medo na negação dos direitos das trabalhadoras domésticas, as mulheres definidas pelo amor, o grande emblema da democracia racial?

\section{Quem pariu Améfrica: trabalho doméstico e controle reprodutivo}

Oitenta e oito reiterou um padrão antigo sobre as domésticas. Como aponta a historiadora Flávia Fernandes de Souza, o tema do trabalho doméstico é relevante no processo de construção da modernidade brasileira. As mancadas, escorregadas ou fraquejadas do discurso dos juristas oferecem pistas para compreender a aparente contradição entre o afeto e a negação de direitos da categoria. Se você quiser saber sobre contratos de trabalho doméstico no século XIX, talvez o melhor lugar para procurar sejam os registros policiais, que registram o profundo medo das elites das mulheres que cuidavam de suas casas e de seus filhos ${ }^{63}$. A historiografia do trabalho doméstico no Brasil registra que,

Embora dependentes de serviçais, os donos das casas os viam com a mesma suspeita destinada aos pobres e negros no geral. Colocar "estranhos" dentro de casa implicava risco. E entre os serviçais domésticos, as mulheres representavam o maior risco, uma vez que costumeiramente executavam o mais pessoal do trabalho doméstico ${ }^{64}$.

Ter serviçais domésticos era tanto um símbolo de status quanto uma necessidade, considerando que o trabalho doméstico incluía uma gama de atividades que supriam aquilo que o poder público só forneceria décadas mais tarde. Sem água encanada e sem energia elétrica para refrigerar alimentos, devia-se buscar água e perecíveis todos os dias, lavar roupa nas fontes e riachos, etc. Os caprichos luxuosos dos patrões, com intermináveis e fartas refeições e roupas e tapeçarias europeias no calor do Brasil, demandavam a realização de atividades perigosas e complexas que exigiam talento e força física ${ }^{65}$.

$\mathrm{Na}$ ordem patriarcal afiançada na antiga tradição portuguesa, que investiu o patriarca de propriedade e autoridade legal sobre esposa, filhos, servos e agregados; as trabalhadoras domésticas, em experiências diversas como mucamas, amas de leite, cozinheiras, lavadeiras, costureiras, carregadoras de água, escravas de ganho que faziam bico em casas de família, africanas, crioulas, mulatas e brancas, cativas, livres e libertas, negociavam proteção e obediência e os trânsitos entre a casa e a rua em suas experiências de liberdade, conectando os mundos das elites e dos pobres e negros, testemunhando ambos de perto ${ }^{66}$.

A arquitetura residencial replicava a tensão entre a casa, familiar, segura e estável, e a rua, suspeita, perigosa e imprevisível: ali perto da cozinha, do lado de fora, junto dos animais e da lavanderia, ficavam as dependências dos escravos e serviçais. Para as domésticas, essa tensão podia se inverter, uma vez que dentro da casa dos patrões estavam submetidas a uma série de riscos ${ }^{67}$.

A proximidade da virada do século trouxe ventos de liberdade e tensões entre patrões e serviçais do-

\footnotetext{
61 NERIS, Natália. A voz e a palavra do movimento negro na Constituinte de 1988. São Paulo: Casa do Direito, 2018.

62 FREYRE, Gilberto. Casa grande \&s senzala. Rio de Janeiro: Record, 2017.

63 TELLES, Lorena Féres da Silva. Libertas entre sobrados: contratos de trabalho doméstico em São Paulo na derrocada da escravidão. 2011. Dissertação (Mestrado em História Social) - Universidade de São Paulo, São Paulo, 2011.

64 GRAHAM, Sandra Lauderdale. House and street. the domestic world of servants and masters in nineteenth-century. Cambridge: Cambridge University Press, 1988.

65 GRAHAM, Sandra Lauderdale. House and street. the domestic world of servants and masters in nineteenth-century. Cambridge: Cambridge University Press, 1988.

66 GRAHAM, Sandra Lauderdale. House and street. the domestic world of servants and masters in nineteenth-century. Cambridge: Cambridge University Press, 1988.

67 GRAHAM, Sandra Lauderdale. House and street. the domestic world of servants and masters in nineteenth-century. Cambridge: Cambridge University Press, 1988.
} 
mésticos. Ao mesmo tempo que se passou a incentivar a contratação de mulheres europeias, em franco processo de substituição da mão de obra dos nacionais negros pelo projeto imigrantista, discursos médicos passaram a descrever amas de leite negras como vetores de transmissão da degenerescência moral da raça negra, na forma de doenças e disposições hereditárias inferiores que seriam transmitidas às crianças brancas. Discursos jornalísticos descreviam as criadas como fofoqueiras suspeitas e agressivas que tinham pouco amor ao trabalho, características creditadas aos defeitos da raça, que dificultavam que a elite encontrasse boas empregadas ${ }^{68}$.

Os códigos de posturas municipais para criados e amas de leite previam mecanismos de controle, não de proteção, prevendo até mesmo dispensa por justa causa por motivo de doença, ou por sair de casa à noite para lazer sem autorização do patrão ${ }^{69}$. Diferente da imagem da doméstica que dedica uma vida inteira de amor a uma única família, os estudos historiográficos indicam uma grande rotatividade da mão de obra doméstica, intermediada por agências de aluguel, embora fosse desejável ter pessoas de confiança, motivo pelo qual era comum pegar crianças de oito a doze anos que fossem treinadas desde a infância para isso ${ }^{70}$.

Nesse aparato normativo que misturava natureza penal e trabalhista, a lei definia penas mais severas a quem executava o serviço portas adentro, embora o poder fosse exercido de forma mais privada do que propriamente pelas instituições públicas. $O$ trabalho portas afora era geralmente executado por mulheres mais velhas, menos férteis e mais confiáveis, ou por meninas muito novas, para quem os perigos e tentações da rua não importavam, que deviam proteger suas senhoras ${ }^{71}$. Essas representações não são problemas do passado. A locação de serviços domésticos se manteve sob a competência da polícia até 1972, com o advento da Lei 5.859. Nas palavras de Lenira de Carvalho, para obter uma carteira de trabalho, diferente dos demais trabalhadores, "Você ia lá, tirava o retrato que nem uma ladrona, botava os dedos todos, tirava de lado, tirava de frente, tirava tudo, pra ter essa carteira" ${ }^{72}$.

Em manuais de Direito Penal atuais ${ }^{73}$, importantes para a formação jurídica e para a fundamentação de decisões judiciais ${ }^{74}$, as empregadas são descritas como potenciais agentes de furto na residência, figuras suspeitas e vingativas que violam a intimidade e segurança do empregador, e que, definitivamente, não fazem parte da familia ${ }^{75}$. Na CPI do trabalho escravo, em 2013, o tema do trabalho doméstico era afastado das discussões como motivo de piada. Um parlamentar em particular sugeriu que a empregada poderia plantar maconha em seu apartamento. Trabalhar de sol a sol e viver no quartinho dos fundos, uma situação comum no Brasil, jamais poderia ser considerado trabalho escravo ${ }^{76}$.

Considerando a relação entre democracia e autoritarismo, mediada pelas chaves da raça e da memória na tradição filosófica ocidental, as permanências autoritárias no constitucionalismo latino-americano, segundo Roberto Gargarella, estão na ausência de mudanças estruturais no que ele chama de "sala de máquinas" da Constituição. Não são somente as graves violações de direitos humanos que determinam lógicas autoritárias,

68 SOUZA, Flávia Fernandes de. Criados, escravos e empregados: O serviço doméstico e seus trabalhadores na construção da modernidade brasileira. Tese (Doutorado em História. Universidade Federal Fluminense. Niterói, 2017.

69 RAMOS, Gabriela Batista Pires. "Como se fosse da família": o trabalho doméstico na Assembleia Nacional Constituinte de 1987/1988. Dissertação (Mestrado em Direito) - Universidade Federal da Bahia, Salvador, 2018.

70 GRAHAM, Sandra Lauderdale. House and street. the domestic world of servants and masters in nineteenth-century. Cambridge: Cambridge University Press, 1988.

${ }^{71}$ GRAHAM, Sandra Lauderdale. House and street. the domestic world of servants and masters in nineteenth-century. Cambridge: Cambridge University Press, 1988.

72 RAMOS, Gabriela Batista Pires. "Como se fosse da família": o trabalho doméstico na Assembleia Nacional Constituinte de 1987/1988. Dissertação (Mestrado em Direito) - Universidade Federal da Bahia, Salvador, 2018. p. 43.

73 PRANDO, Camila Cardoso de Mello. As margens da criminologia: desafios desde uma epistemologia feminista. No prelo, 2016.

74 NASCIMENTO, Guilherme; DUARTE, Evandro; QUEIROZ, Marcos. O silêncio dos juristas: a imunidade tributária sobre templo de qualquer culto e as religiões de matriz africana à luz da constituição de 1988. Revista Quaestio Iuris, Rio de Janeiro, v. 10, n. 2, p. 1162-1180, 2017.

75 NUCCI, Guilherme de Souza. Manual de Direito Penal. 10. ed. Rio de Janeiro: Forense, 2014.

76 ALVES, Raissa Roussenq. Entre o silêncio e a negação: trabalho escravo contemporâneo sob a ótica da população negra. Belo Horizonte: Letramento, 2019. 
mas as formas de organização do Judiciário, do Legislativo e do Executivo, que pouco se alteraram nos últimos séculos. Apesar de alguns avanços, não alcançamos esse núcleo da maquinaria democrática ${ }^{77}$.

Nem mesmo esses poucos avanços atingiram as domésticas. Na onda de consolidação de direitos econômicos e laborais no início do século XX, representada no Brasil pela Era Vargas, elas foram expressamente excluídas pela CLT em 1943, bem como do Decreto 19.770/1931, que inaugurou oficialmente a regulação do sindicalismo no Brasil. Na onda de reformas para avanço dos direitos humanos na segunda metade do século XX, na qual se insere a Constituição de 1988, conseguiram emplacar apenas nove direitos fundamentais. Elas tiveram direitos básicos assegurados só depois da Emenda Constitucional 72 de 2013 e da Lei Complementar 150 de 2015, que ainda não as equiparou aos urbanos e rurais. A Convenção 189 da OIT - Organização Internacional do Trabalho, que traz recomendações sobre o trabalho doméstico decente, foi ratificada só no ano de 2018.

O que explica essa democracia de escravos, paradoxo e disjunção moral absoluta que permite a coexistência de uma comunidade de semelhantes, regida teoricamente pela lei da igualdade, e uma categoria de não semelhantes, também instituída por lei, em que estes à priori não tem qualquer direito a ter direitos ${ }^{78}$ ? Para Dorothy Roberts, a hereditariedade da raça, enquanto traço biológico transmitido pelos úteros negros, resolve as contradições entre escravidão e liberdade ao traçar hierarquias da vida humana por uma linha de cor:

Somente uma teoria enraizada na natureza poderia sistematicamente dar conta da anomalia da escravidão existindo em uma república fundada em um compromisso radical com a liberdade, a igualdade e os direitos naturais. [...] Porque a raça foi definida como um traço hereditário, preservar distinções raciais requereu o policiamento da reprodução. [...]

A procriação branca é geralmente pensada como uma atividade benéfica: ela traz alegria pessoal e permite que a nação floresça. A procriação negra, por outro lado, é tratada como uma forma de degeneração ${ }^{79}$.

A advogada estadunidense Kimberlé Crenshaw afirma que não foi a Declaração de Independência, a Constituição ou as estrelas e listras que pariram a América. Foi a vagina negra que botou o ovo de ouro, a propriedade valiosa que moveu a economia global por séculos e financiou o nascimento dos Estados nacionais: o escravo ${ }^{80}$. "Trabalho" é muito pouco para nomear o que foi tirado delas em nome do progresso da nação.

A escravidão, processo de destituição cívica que remove o sujeito de qualquer rede de parentesco para convertê-lo em um estranho/mercadoria, é, em muitos sentidos, a experiência de perder a mãe ${ }^{81}$. Antes mesmo da concepção, seus filhos já eram objeto de propriedade do senhor, a expectativa de lucros futuros. Também por isso, a reprodução foi arena de resistência ao regime escravista ${ }^{82}$. Margareth Garner, caso real que inspirou o romance Amada de Toni Morrison, ao fugir da escravidão e ser recapturada, mata uma de suas filhas com uma faca de açougueiro e tenta matar os outros. Exercendo radicalmente seu direito à maternidade, entendia que morrer era melhor que a escravidão. "Não foi nenhum desespero selvagem que a motivou, mas uma calma determinação de que, se ela não podia encontrar a liberdade aqui, ela a conseguiria com os anjos... [...] Ela havia dito que sua filha jamais sofreria como ela" ${ }^{\prime 3}$.

Mulheres negras certamente não são sinônimos de vaginas negras, mas a linguagem gestacional revela aspectos importantes da violência secular infligida sobre seus corpos. Como uma passagem do meio domés-

\footnotetext{
GARGARELLA, Roberto. Latin american constitutionalism: social rights and the "engine room" of the constitution. Notre Dame Journal of International \& Comparative Law, v. 4, n. 1, 2014.

78 MBEMBE, Achille. Políticas da inimizade. Lisboa: Antígona, 2017.

79 ROBERTS, Dorothy. Killing the Black Body: race, reproduction, and the meaning of liberty. New York: Vintage Books, 2017. p.

9. Tradução livre.

80 CRENSHAW, Kimberlé. Respect. In: ENSLER, Eve. The Vagina Monologues. EUA: Virago, 2002.

81 HARTMAN, Saidiya. Lose your mother: a journey along the Atlantic slave rout. New York: Farrar, Straus and Giroux, 2008.

82 ROBERTS, Dorothy. Killing the Black Body: race, reproduction, and the meaning of liberty. New York: Vintage Books, 2017. Tradução livre.

83 GILROY, Paul. O Atlântico negro: modernidade e dupla consciência. São Paulo: Editora 34; Rio de Janeiro: Universidade Candido Mendes, Centro de Estudos Afro-Asiáticos, 2012. p. 146.
} 
tica, o canal vaginal foi convertido em uma máquina de reprodução da negritude como abjeção. "O navio negreiro é um útero/abismo. A plantation é a barriga do mundo. Partus serquitur ventrem - a criança segue a barriga" ${ }^{\prime 4}$. O princípio romano Partus serquitur ventrem designa que

a origem, o status do recém-nascido, não é determinado pelo pai, mas pela mãe, então, o senhor podia procriar à vontade, tornava-se um garanhão, e todos os filhos dele acabavam sendo negros e escravos, porque aquele núcleo legal da família branca não era tocado pela miscigenação ${ }^{85}$.

Segundo a historiadora Martha Santos, o princípio que fundamenta a hereditariedade do status de escravizado pela linha materna tornou-se uma peça central no debate sobre a manutenção da escravidão desde a proibição do tráfico transatlântico em 1831. Em um contexto de interrupção do fluxo de chegada de novos carregamentos de escravizados, de crescente demanda por mão de obra no Sudeste e de declínio da economia açucareira no Nordeste, o reabastecimento do mercado interno contou com a reprodução e com o cuidado das cativas. As "mães escravas" teriam também o papel de pacificar e estabilizar a mão de obra ${ }^{86}$.

A Lei do Ventre Livre revela a dimensão de gênero do Pacto Trabalhista. Ao passo que libertava os filhos dessas mulheres, a lei os forçava a servir aos senhores das genitoras até os 21 anos; em uma lógica de compensação pela perda da propriedade e do lucro proveniente de seu trabalho, repactuando novas formas de escravidão por meio do controle do fruto dos úteros negros.

As “mães escravas" povoaram não só as disputas legislativas da época, mas também discursos acadêmicos e manuais de empresas agrícolas publicados por senhores de escravos. Encontra-se, entre uma e outra técnica de plantio e colheita para otimizar a produção, instruções específicas sobre a promoção de casamentos entre escravizados para estimular a reprodução natural. Seu trabalho reprodutivo era fundamental não somente para a economia nacional, parindo e criando novos trabalhadores, mas para reconciliar as contradições entre a prática da escravidão e o avanço de ideias liberais na construção de um Brasil moderno ${ }^{87}$.

A produção de representações sobre mulheres negras, inspiradas naquelas que criaram e amamentaram os filhos das elites, tem destaque na disputa pelos sentidos da nação brasileira. A mãe preta é um ícone frequente na literatura modernista como símbolo nostálgico, alegoria da confraternização inter-racial brasileira por seus atributos maternais e afetivos, o contraponto dócil do escravo revoltado e vingativo ${ }^{88}$.

Embora a mãe preta de Gilberto Freyre se apresente como uma figura tipicamente brasileira, símbolo das condições particulares que teriam possibilitado a construção do país da democracia racial, ela é fortemente inspirada na literatura postbellum do Sul escravagista dos EUA derrotado na Guerra de Secessão, que criou narrativas memoriais gloriosas de um passado que então estava em disputa ${ }^{89}$. Fantasias coloniais sobre mulheres pretas cuidadoras ou reprodutoras, presentes em diversos lugares da diáspora, revelam dinâmicas e estratégias transnacionais de controle da população negra compartilhadas pelas elites brancas, símbolo de reconciliação com o passado escravista.

Da Tia Nastácia, cozinheira do Sítio do Pica-Pau Amarelo por trás das receitas da Dona Benta, à Tia

84 HARTMAN, Saidiya. The belly of the world: a note on Black women's labor. Souls: A Critical Journal of Black Politics, Culture, and Society, v. 18, n. 1, p. 166-173, 2016.

85 Discurso do sociólogo e deputado constituinte Florestan Fernandes. BRASIL. Senado Federal. Atas da Subcomissão dos Negros, Populações Indígenas, Pessoas Deficientes e Minorias. Brasília: Senado Federal, 1987. Disponível em: https://www.senado.leg.br/publicacoes/anais/asp/CT_Abertura.asp. Acesso em: 01 dez. 2019.

86 SANTOS, Martha M. "Slave Mothers", Partus Sequitur Ventrem, and the Naturalization of Slave Reproduction in NineteenthCentury Brazil. Tempo Niterói, v. 22, n. 41, p. 467-484, set./dez. 2016. Disponível em: https://www.scielo.br/scielo.php?script=sci_ arttext\&pid=S1413-77042016000300467. Acesso em: 22 maio 2020.

87 SANTOS, Martha M. "Slave Mothers", Partus Sequitur Ventrem, and the Naturalization of Slave Reproduction in NineteenthCentury Brazil. Tempo Niterói, v. 22, n. 41, p. 467-484, set./dez. 2016. Disponível em: https://www.scielo.br/scielo.php?script=sci_ arttext\&pid=S1413-77042016000300467. Acesso em: 22 maio 2020.

88 RONCADOR, Sônia. A doméstica imaginária: literatura, testemunhos e a invenção da empregada doméstica no Brasil (1889-1999). Brasília: Universidade de Brasília, 2008.

89 SIQUEIRA, Carlos Henrique R. de. A alegoria patriarcal: Escravidão, raça e nação nos Estados Unidos e no Brasil. 2007. Tese (Doutorado em Ciências Sociais) - Centro de Pesquisa e Pós-Graduação sobre as Américas, Universidade de Brasília, Brasília, 2007. 
Jemima, usada desde 1893 como rosto de uma marca de mistura para panqueca que leva seu nome, chamam atenção para o papel das representações de mulheres negras na alimentação e culinária no Brasil e nos EUA e suas implicações para a construção das respectivas culturas e identidades nacionais ${ }^{90}$.

$\mathrm{Na}$ década de 1920, houve uma proposta de estabelecer o dia 28 de setembro como Dia da Mãe Preta, em referência à data de promulgação da Lei do Ventre Livre em 1871, que celebrava a benevolência que caracterizaria as relações raciais no Brasil. Levantada inicialmente pela elite branca, foi endossada por intelectuais da imprensa negra, sobretudo homens, que se apropriaram criticamente dela como signo de integração para acessar a democracia, representada pela presença de mulheres negras nas famílias brancas como amas de leite e servas domésticas. Em 1955, quando da inauguração de uma estátua em homenagem à Mãe Preta em São Paulo, ela seria rejeitada pelo movimento negro, que passara a identificá-la como signo de subordinação racial ${ }^{11}$.

É importante destacar que nenhuma dessas imagens corresponde àquelas produzidas nos espaços de articulação política da categoria das trabalhadoras domésticas a partir da década de 1930, que desde o início buscaram reconhecimento profissional, direito a sindicalização e equiparação de direitos, de modo a valorizar o trabalho doméstico. Dona Laudelina de Campos Mello, a pioneira que fundou a Associação Beneficente de Empregadas Domésticas de Santos em 1936, e que teve a chance de ver, bem velhinha, os frutos de sua incansável luta política na Constituição de 1988; estabeleceu as diretrizes políticas, sociais e trabalhistas para o movimento de empregadas domésticas: pressão ao Estado para regulamentar a profissão, formação política das trabalhadoras para inserção em espaços de lutas coletivas, e capacitação profissional. Essa líder comunitária, militante negra, cujo carisma, sabedoria e eloquência provocam ainda hoje o fascínio e a admiração de quem a conheceu, é a griot da categoria. Mais que direitos trabalhistas, ela ofereceu um universo de cultura, educação e afeto negado às mulheres excluídas da sociedade, condenadas à solidão do quartinho de empregada ${ }^{92}$.

\section{Memória em pretuguês: amefricanidade e o papel da mãe}

A categoria político-cultural de amefricanidade, desenvolvida pela antropóloga Lélia Gonzalez, erige-se como uma ferramenta analítica potente para compreender essas contradições, que oferece uma versão alternativa do texto nacional caracterizada não pela harmonia, mas pela negação de conflitos e tensões raciais. Amparada pelo diálogo com os estudos psicanalíticos, na esteira de Fanon, por razões de ordem do inconsciente, Lélia entende o racismo como neurose cultural brasileira ${ }^{93}$. Uma vez que o racismo é irracional, a razão é insuficiente para compreender como ele opera" " "Psicanálise e Lógica, uma se funda sobre o que a outra elimina. A análise encontra seus bens nas latas de lixo da lógica. Ou ainda: a análise desencadeia o que a lógica doméstica"95 - daí a importância da linguagem, e especificamente do pretuguês.

Embora se apresente como excepcionalmente livre de racismo, apartado das demais nações escravistas, o Brasil, país que recebeu quase metade do contingente de africanos escravizados de todo o mundo atlântico,

\footnotetext{
90 MACHADO, Taís Sant'Anna. Paralelos entre a mãe-preta brasileira e a mammy estadunidense? Sobre a identidade, culinária, raça e diáspora negra. In: JORNADA DE ESTUDOS NEGROS DA UNB, 1., 2016, Brasília. Anais [...]. Brasília: UnB, 2016, p. 119-137.

91 ALBERTO, Paulina. Terms of inclusion: black intellectuals in twentieth-century Brazil. North Carolina: The University of North Carolina Press, 2011.

92 PINTO, Elisabete Aparecida. Etnicidade, gênero e educação: trajetória de vida de Laudelina de Campos Mello. São Paulo: Anita Garibaldi, 2015.

93 GONZALEZ, Lélia. A categoria político-cultural de amefricanidade. Tempo Brasileiro, Rio de Janeiro, n. 92/93, p. 69-82, jan./ jun. 1988.

94 FANON, Frantz. Pele negra, máscaras brancas. Salvador: EDUFBA, 2008.

95 MILLER, 1976 apud GONZALEZ, Lélia. Racismo e sexismo na cultura brasileira. Revista Ciências Sociais Hoje - Anpocs, p. 223244,1984
} 
o último das Américas a abolir a escravidão, que têm a maior população negra do planeta fora do continente africano; forjou-se sobre a história clássica da colonização: um homem branco que sucumbiu à "instituição peculiar" e uma mulher preta que sucumbiu a ele, povoando o terreiro de bastardos ${ }^{96}$. No mito da democracia racial, o homem negro sai de cena, junto com a mulher branca; e os povos indígenas são descritos como “já desaparecendo", substituídos pela mão de obra escrava africana. O branco e a negra, esses dois personagens principais antagônicos, coexistem pela suposta plasticidade, adaptabilidade e ausência de preconceito do português, e pela disponibilidade sexual e amor abnegado da mulher colonizada ${ }^{97}$.

Racismo e sexismo se encontram na cultura brasileira nas imagens de mulheres negras, a saber: mãe preta e mucama, cuja dimensão econômica é expressa pela doméstica, o cotidiano de exploração, e a dimensão sexual, pela mulata, a rainha excepcionalmente exaltada no rito carnavalesco ${ }^{98}$. A celebração da hospitalidade, da mistura, da culinária, do samba, da bunda dependem da violência contra seus corpos, da exploração de seu trabalho e do apagamento de sua agência. Esse repertório demarca o lugar das mulheres negras na narrativa hegemônica sobre a formação nacional como figuras politicamente passivas e sexualmente disponíveis, que amam seus senhores e existem para servir ${ }^{99}$. Embora se apresentem como tipicamente brasileiras, elas sinalizam expectativas sobre os papeis desempenhados por mulheres negras por todo o mundo moderno. Mãe preta e mucama expressam o duplo entre a doméstica assexual obediente e a prostituta primitiva sexualizada, que misturam medo, desejo e violência branca contra corpos negros ${ }^{100}$.

Amefricanidade se trata, portanto, de uma proposta transnacional de compreensão das Américas que rejeita a ideia de latinidade, herança colonial ibérica, e indica as particularidades das formas de colonização de Portugal e Espanha, marcadas por uma intensa estratificação social registrada na máxima "No Brasil não existe racismo porque o negro sabe seu lugar", em gradações de cor que invariavelmente terão o branco no topo ${ }^{101}$. O mito da democracia racial é expressão da ideologia do branqueamento, que tem como efeito a fragmentação da identidade étnica e introjeção do desejo de "purificar o sangue"102. Assim, também os colonizados negam sua própria raça e cultura.

Dessa forma, a afirmação de que todos são iguais perante a lei assume um caráter claramente formalista em nossas sociedades. O racismo latino-americano é suficientemente sofisticado para manter negros e índios na condição de segmentos subordinados dentro das classes mais exploradas, graças à sua forma ideológica mais efetiva: a ideologia do branqueamento [...]. Transmitida pela mídia de massa e pelos aparatos ideológicos tradicionais, ela reproduz e perpetua a crença de que as classificações e valores da cultura ocidental branca são os únicos verdadeiros e universais. ${ }^{103}$

$\mathrm{Na}$ contramão da anglo e francofonia que predominam nos estudos clássicos sobre relações raciais, os quais enfatizam as marés do lado norte do circuito triangular entre África, América e Europa do chamado Atlântico $\mathrm{Negro}^{104}$, a amefricanidade questiona ainda a centralidade dos Estados Unidos nas narrativas sobre as resistências negras no continente, num esforço de democratização geográfica, linguística e ideológica sobre a experiência diaspórica, transpondo fronteiras para aprofundar as compreensões sobre o conjunto da América do Sul, Central, do Norte e Insular.

96 HARTMAN, Saidiya. Lose your mother: a journey along the Atlantic slave rout. New York: Farrar, Straus and Giroux, 2008.

97 SILVA, Denise Ferreira da. À brasileira: racialidade e a escrita de um desejo destrutivo. Rev. Estud. Fem., Florianópolis, v. 14, n. 1, p. 61-83, abr. 2006. Disponível em: http://www.scielo.br/scielo.php?script=sci_arttext\&pid=S0104-026X2006000100005\&lng= en\&nrm=iso. Acesso em: 23 nov. 2017.

98 GONZALEZ, Lélia. Racismo e sexismo na cultura brasileira. Revista Ciências Sociais Hoje - Anpocs, p. 223-244, 1984.

99 GONZALEZ, Lélia. Racismo e sexismo na cultura brasileira. Revista Ciências Sociais Hoje - Anpocs, p. 223-244, 1984.

100 KILOMBA, Grada. Memórias da Plantação: episódios de racismo cotidiano. Rio de Janeiro: Cobogó, 2019.

101 GONZALEZ, Lélia. A categoria político-cultural de amefricanidade. Tempo Brasileiro, Rio de Janeiro, n. 92/93, p. 69-82, jan./jun. 1988.

102 GONZALEZ, Lélia. Por um feminismo afrolatinoamericano. In: GONZALEZ, Lélia. Primavera para rosas negras. São Paulo: UCPA Editora, 2018. p. 307-320.

103 GONZALEZ, Lélia. Por um feminismo afrolatinoamericano. In: GONZALEZ, Lélia. Primavera para rosas negras. São Paulo: UCPA Editora, 2018. p. 307-320. p. 312.

104 GILROY, Paul. O Atlântico negro: modernidade e dupla consciência. São Paulo: Editora 34; Rio de Janeiro: Universidade Candido Mendes, Centro de Estudos Afro-Asiáticos, 2012. 
Seu valor metodológico, a meu ver, está no fato de permitir resgatar uma unidade específica, historicamente forjada no interior de diferentes sociedades que se formaram numa determinada parte do mundo. Portanto, a Améfrica, enquanto sistema etnogeográfico de referência, é uma criação nossa e de nossos antepassados no continente em que vivemos, inspirados em modelos africanos. [...]

Reconhecê-la é, em última instância, reconhecer o gigantesco trabalho de dinâmica cultural que não nos leva para o lado do Atlântico, mas que nos trás de lá e nos transforma no que somos hoje: amefricanos [grifo meu] ${ }^{105}$.

Mais do que "sobrevivências" de um passado longínquo, uma vez que o registro não é linear e evolucionista, a amefricanidade se refere à explosão criadora das dinâmicas que nos transformaram na travessia, que não se resume à violência colonial, mas a precede e transcende, inserida no contexto multirracial e pluricultural das sociedades da região ${ }^{106}$; e, ao mesmo tempo, nas dinâmicas globais da diáspora africana, compreendendo o colonialismo como a face oculta e constitutiva da modernidade ${ }^{107}$.

A amefricanidade descreve uma dialética entre consciência e memória. Lélia descreve a consciência como lugar do discurso dominante, da alienação, do esquecimento, ao passo que a memória seria o lugar do não saber que se conhece, de emergência da verdade que a consciência busca encobrir. Em outras palavras, trata-se de uma tensão entre imagem e linguagem: as imagens construídas pelo colonizador, que legitimam a história espetacular dos "vencedores"; e a linguagem que codifica nossas formas de compreender o mundo, e, inevitavelmente, guarda as inscrições de uma história que não foi escrita. A memória, contudo, fala por meio das mancadas da consciência, presentes nos discursos dos juristas ${ }^{108}$.

Gilberto Freyre, considerado um dos grandes intérpretes da nação, volta-se para um passado rural pré-capitalista informado por sua própria infância no engenho para construir sua narrativa sobre a formação da família brasileira no regime da economia patriarcal ${ }^{109}$. A partir de um Nordeste mestiço e miserável, que mais tarde se tornaria o grande fornecedor de mão de obra barata do país, acionando características climáticas, biológicas e folclóricas ${ }^{110}$, ele elege a) a casa como microcosmo político onde se desenvolve a história da nação, b) o patriarcado como concepção moderna de autoridade jurídica e c) a família como grande fator de colonização do Brasil, na qual as mulheres negras, na qualidade de escravas domésticas, têm um papel central ${ }^{111}$. Nesse sentido, estabelece uma história mítica das trabalhadoras domésticas e da divisão sexual e racial do trabalho ${ }^{112}$.

Como diria Lélia, a democracia racial, "como todo mito, oculta algo para além daquilo que mostra". Segundo Denise Ferreira as Silva, embora haja uma aparente celebração da mestiçagem e da diversidade cultural na narrativa oficial sobre a formação nacional brasileira, é o homem branco português, um Eu patriarcal tradicional, o verdadeiro construtor espiritual da nação, que empreende a civilização brasileira nos trópicos, um sujeito histórico cuja violência é produtora da nação. Seu empreendimento inscreve um duplo movimento histórico: ao passo que traça uma trajetória teleológica do Espírito em direção ao progresso e à brancura, traça uma trajetória escatológica dos Outros, negros e indígenas, sujeitos da morte, condenados a desaparecer ${ }^{113}$ - pelo extermínio ou pela assimilação/mestiçagem.

105 GONZALEZ, Lélia. A categoria político-cultural de amefricanidade. Tempo Brasileiro, Rio de Janeiro, n. 92/93, p. 69-82, jan./ jun. 1988. p. 77-79.

106 GONZALEZ, Lélia. A categoria político-cultural de amefricanidade. Tempo Brasileiro, Rio de Janeiro, n. 92/93, p. 69-82, jan./ jun. 1988.

107 GILROY, Paul. O Atlântico negro: modernidade e dupla consciência. São Paulo: Editora 34; Rio de Janeiro: Universidade Candido Mendes, Centro de Estudos Afro-Asiáticos, 2012.

108 GONZALEZ, Lélia. Racismo e sexismo na cultura brasileira. Revista Ciências Sociais Hoje - Anpocs, p. 223-244, 1984.

109 FREYRE, Gilberto. Casa grande \& senzala. Rio de Janeiro: Record, 2017.

110 ALVES, Raissa Roussenq. Entre o silêncio e a negação: trabalho escravo contemporâneo sob a ótica da população negra. Belo Horizonte: Letramento, 2019.

111 SILVA, Denise Ferreira da. À brasileira: racialidade e a escrita de um desejo destrutivo. Rev. Estud. Fem., Florianópolis, v. 14, n. 1, p. 61-83, abr. 2006. Disponível em: http://www.scielo.br/scielo.php?script=sci_arttext\&pid=S0104-026X2006000100005\&lng= en\&nrm=iso. Acesso em: 23 nov. 2017.

112 BERNARDINO-COSTA, Joaze. Sindicatos das trabalhadoras domésticas no Brasil: teorias de descolonização e saberes subalternos. 2007. Tese (Doutorado em Sociologia) - Universidade de Brasília, Brasília, 2007.

113 SILVA, Denise Ferreira da. À brasileira: racialidade e a escrita de um desejo destrutivo. Rev. Estud. Fem., Florianópolis, v. 14, n. 
O uso do corpo da mulher escravizada por meio da violência sexual produz o mestiço, um sujeito social, trabalhador, concreto, produto da ação modeladora do português, que só manteria traços de africanidade no corpo, progressivamente embranquecido. O mestiço, símbolo produtivo e unificador da brasilidade, um sujeito social precário nem negro nem branco, condenado ao autoapagamento, é apresentado como prova da ausência de preconceito racial, embora seja produto da violência racista ${ }^{114}$.

A divisão sexual e a divisão racial do trabalho adiam duplamente o engajamento do senhor com a natureza, ou seja, permitem que fique longe do trabalho exigido para produção/alimentação (plantation) e reprodução/procriação (trabalho doméstico). As instituições do casamento e da escravidão legitimam seu poder absoluto. Ele encarna a regulação jurídico-econômica, não se subordina a ela. A violência da exploração que garante sua reprodução, descendência e enriquecimento não constitui uma transgressão às normas. Na verdade, é possibilitada por elas. Os frutos da exploração do corpo da escrava são a única contribuição real para a nação, uma vez que a cultura brasileira seria legado da Europa ibérica, que assimilaria as raças inferiores ${ }^{115}$.

Se a nova moda é a necropolítica - ou a leitura profundamente equivocada de Achille Mbembe -, a velha democracia racial articula o que sempre esteve em alta na política nacional: a tradição conservadora, agrícola e religiosa, os valores da família latifundiária escravocrata, o nepotismo ou oligarquismo que converteu o Brasil na "aristocracia colonial mais poderosa da América", o direito dos homens brancos sobre tudo. Para Freyre, o sadomasoquismo seria o elemento determinante nas relações entre senhores e escravas, que transborda as fronteiras da esfera da vida sexual e doméstica e determina a tradição social e política conservadora do país. O sadomasoquismo justificaria o fracasso da democracia e a vocação autoritária no país ${ }^{116}$. Seríamos dominadas porque gostamos de sofrer.

A nossa tradição revolucionária, liberal, demagógica, é antes aparente e limitada a focos de fácil profilaxia política: no íntimo, o que o grosso do que se pode chamar "povo brasileiro" ainda goza é a pressão sobre ele de um governo másculo e corajosamente autocrático. Mesmo em sinceras expressões individuais [...] de mística revolucionária, de messianismo, de identificação do redentor com a massa a redimir pelo sacrifício de vida ou de liberdade pessoal, sente-se o laivo ou o resíduo masoquista: menos a vontade de reformar ou corrigir determinados vícios de organização política ou econômica que o puro gosto de sofrer, de ser vítima, ou de sacrificar-se [grifo meu $]^{117}$.

Quem desmascara essa tradição política autoritária e seu projeto fracassado de desafricanizar o Brasil é a mãe preta, que ensinou os brancos a falar às custas de seu próprio silêncio. Inserindo a criança brasileira na ordem da cultura por meio da linguagem, contando as primeiras histórias de bicho e de mal-assombrado, embalando seu sono com canções de ninar, ela é a prova de que as construções do inconsciente nacional não são exclusivamente brancas e europeias, mas amefricanas. Bagunçando o esquema de Édipo, se ela amamenta, cuida, dá banho, efetivamente exercendo o papel materno, a mãe preta é a mãe na cultura brasileira ${ }^{118}$.

A história do emprego doméstico no Brasil certamente não confirma a tese do sadomasoquismo. Pelo contrário, registra a violência privada e os esforços estatais de controle e punição, bem como o sofrimento e a resistência das sobreviventes das casas grandes, que produziram outras interpretações sobre o fenômeno. Para Lélia, a negação, ou denegação, é o traço distintivo do racismo à brasileira, que se volta justamente contra aqueles que são evidência da ladinoamefricanidade denegada. A negação, segundo Grada Kilomba, é

\footnotetext{
1, p. 61-83, abr. 2006. Disponível em: http://www.scielo.br/scielo.php?script=sci_arttext\&pid=S0104-026X2006000100005\&lng= en\&nrm=iso. Acesso em: 23 nov. 2017.

114 SILVA, Denise Ferreira da. À brasileira: racialidade e a escrita de um desejo destrutivo. Rev. Estud. Fem., Florianópolis, v. 14 , n. 1, p. 61-83, abr. 2006. Disponível em: http://www.scielo.br/scielo.php?script=sci_arttext\&pid=S0104-026X2006000100005\&lng= en\&nrm=iso. Acesso em: 23 nov. 2017.

115 SILVA, Denise Ferreira da. À brasileira: racialidade e a escrita de um desejo destrutivo. Rev. Estud. Fem., Florianópolis, v. 14 , n. 1, p. 61-83, abr. 2006. Disponível em: http://www.scielo.br/scielo.php?script=sci_arttext\&pid=S0104-026X2006000100005\&lng= en\&nrm=iso. Acesso em: 23 nov. 2017.

116 FREYRE, Gilberto. Casa grande \& senzala. Rio de Janeiro: Record, 2017.

117 FREYRE, Gilberto. Casa grande \& senzala. Rio de Janeiro: Record, 2017. p. 144.

118 GONZALEZ, Lélia. Racismo e sexismo na cultura brasileira. Revista Ciências Sociais Hoje - Anpocs, p. 223-244, 1984.
} 
um processo psicológico no qual o senhor nega seu projeto de colonização e o impõe ao colonizado, promovendo uma inversão na qual o invasor sanguinário se torna a vítima compassiva, ao passo que o Outro se torna o inimigo intrusivo, o bandido violento que quer tomar o que pertence a ele. "Estamos levando o que é Delas/es" torna-se "Elas/es estão tomando o que é Nosso", ocultando a informação original e convertendo oprimido em opressor ${ }^{119}$.

A partir de uma leitura crítica do complexo de Édipo, Kilomba indica que esse mecanismo opera como estratégia de preservação do patriarcado branco. Para escapar do conflito com a figura paterna, a autoridade patriarcal, o sujeito branco é, simbolicamente, a criança cujo trono é ameaçado pelos Outros, a quem deve destruir, garantindo o acesso ao poder e a manutenção de sentimentos positivos em relação à família e à nação ${ }^{120}$. Permite-se, assim, a transmissão intergeracional de privilégios públicos e privados que asseguram a sobrevivência material dos brancos e a possibilidade de controlarem aspectos cruciais da vida de outras pessoas, legitimando a brancura como direito de propriedade ${ }^{121}$. Espiando por baixo do véu da ignorância, guiados pela emoção, os pais de família garantem aos seus filhos - legítimos! - seu patrimônio e seu poder ${ }^{122}$.

Podemos dizer que a informação "a mulata é fogosa" dissimula a informação original de que o homem branco é um estuprador. Invertendo os papeis, ela se torna a agressora em potencial, que precisa ser vigiada e controlada. Projetando sobre o Outro a parte do ego que se recusa a ver em si mesmo, o sujeito branco deposita os aspectos desonrosos sobre o objeto externo ruim. Como uma tela de projeção, sujeitos negros incorporam a sexualidade e a agressividade, aspectos que a sociedade branca tem reprimido e transformado em tabu, coincidindo ao mesmo tempo

com a ameaça, o perigo, o violento, o excitante e também o sujo, mas desejável - permitindo à branquitude olhar para si como moralmente ideal, decente, civilizada e majestosamente generosa, em controle total e livre da inquietude que sua história causa ${ }^{123}$.

Escondida na cozinha, no elevador de serviço ou no quartinho de empregada, longe das vistas da culpabilidade branca, ela é a prova do crime, que, mesmo denegada, aparece até no texto constitucional124. "Como se fosse da família”, o artifício do ego branco pra dar conta da figura que expõe as mais íntimas contradições e monstruosidades da branquitude, não demarca relações de parentesco, mas de propriedade. A continuidade de padrões de poder escravistas na regulação do emprego doméstico tem sido questionada de forma contundente pela organização associativa/sindical das trabalhadoras brasileiras domésticas ao longo de seus mais de 80 anos de atividade.

O trabalho das mulheres negras, as mulas do mundo que construíram a modernidade, dificilmente é reconhecido enquanto trabalho, uma vez que sua exploração é creditada a uma inferioridade natural, fora de relações contratuais ${ }^{125}$. Ele também ocupa um não-lugar na tradição radical negra, fora das narrativas heroicas em que escravos haitianos se levantam contra o colonialismo ao perceberem o valor de seu trabalho. Executado dentro ou fora de casa, desafia não só a linguagem da fábrica e do sindicato, mas do quilombo e da revolução. Contudo, foi esse trabalho, injustamente lido como passividade, o responsável pela sobrevivência das comunidades negras ${ }^{126}$. A amefricanidade guarda um projeto constitucional que lhe confere uma posição central.

\footnotetext{
119 KILOMBA, Grada. Memórias da Plantação: episódios de racismo cotidiano. Rio de Janeiro: Cobogó, 2019.

120 KILOMBA, Grada. Desobediências poéticas. São Paulo, 2018. Disponível em: http://pinacoteca.org.br/wp-content/uploads/2019/07/AF06_gradakilomba_miolo_baixa.pdf Acesso em: 07 out. 2020.

121 HARRIS, Cheryl I. Whiteness as property. Harvard Law Review, v. 106, n. 8, jun. 1993.

122 OKIN, Susan Moller. Justice, Gender and the Family. In: BAILEY, A. et al. The Broadview anthology of social and political thought. essential readings. Peterborough: Broadview Press, 2012.

123 KILOMBA, Grada. Memórias da Plantação: episódios de racismo cotidiano. Rio de Janeiro: Cobogó, 2019. p. 34-37.

124 GONZALEZ, Lélia. Racismo e sexismo na cultura brasileira. Revista Ciências Sociais Hoje - Anpocs, p. 223-244, 1984.

125 FEDERICI, Silvia. O Calibã e a bruxa: mulheres, corpo e acumulação primitiva. São Paulo: Elefante, 2018.

126 HARTMAN, Saidiya. The belly of the world: a note on Black women's labor. Souls: A Critical Journal of Black. Politics, Culture, and Society, v. 18, n. 1, p. 166-173, 2016.
} 
Nossas antepassadas vieram da África para o Brasil como escravas para trabalharem nas plantações de cana de açúcar, nos engenhos, etc. Nos reinos e impérios africanos de onde vieram, as mulheres eram tratadas com grande respeito e, em muitos deles, elas até chegavam a ter participação política. A valorização das mulheres pelas diferentes culturas negro-africanas sempre se deu a partir da função materna. É por aí que a gente pode entender, por exemplo, a importância que as "mães" e as "tias" iriam ter não só na formação e desenvolvimento das religiões afro-brasileiras (candomblé, tambor de mina, umbanda etc.), como também em outros setores da cultura negra no Brasil ${ }^{127}$.

Não há memória sem ancestralidade, e, definitivamente, não há ancestral sem mãe. A tradução de rainhas africanas na diáspora, restituídas na figura das Ialodês pelo movimento feminista negro no Brasil ${ }^{128}$, sinaliza que a centralidade da instituição iorubá de Iyá ${ }^{129}$ foi reinventada pelas mulheres negras brasileiras que são chefes de família e exercem papeis de liderança em suas comunidades - inclusive mediadas pelas políticas de respeitabilidade da Igreja ${ }^{130}$-, várias das quais tiveram no emprego doméstico a possibilidade de inserção profissional que provê sustento coletivo ${ }^{131}$.

Lélia Gonzalez oferece um horizonte político democrático a partir das lutas por liberdade das mulheres africanas, que mesmo em condições precárias, garantiram a sobrevivência de suas comunidades e transmitiram valores afro-brasileiros aos seus filhos e aos brancos que criaram. Nas palavras de Thula Pires, autora fundamental no projeto de construção de um constitucionalismo ladinoamefricano, "A África civilizou o Brasil porque lhe deu um povo"132.

[Não] é ressaltado pela história oficial o fato de que o primeiro Estado livre de todo o continente americano existiu no Brasil colonial, uma denúncia viva do sistema implantado pelos europeus no continente. Estamos falando da República Negra de Palmares, que durante um século (1595-1695) floresceu na capitania de Pernambuco. O que essa história não enfatiza é que o maior esforço bélico despendido pelas autoridades foi contra Palmares [...]. O que ela não enfatiza é que Palmares foi a primeira tentativa brasileira no sentido de criação de uma sociedade democrática e igualitária que, em termos políticos e socioeconômicos, realizou um grande avanço. Sob a liderança da figura genial de Zumbi, ali existiu uma efetiva harmonia racial já que sua população, constituída por negros, indios, brancos e mestiços, vivia do trabalho livre cujos benefícios revertiam para todos, sem exceção. [...] Palmares foi o berço da nacionalidade brasileira, [...] onde a lingua oficial era o pretuguês ${ }^{133}$.

A centralidade da instituição da família para compreensão do fenômeno colonial, geralmente descrito como a tomada da masculinidade do colonizado, eclipsando suas implicações de gênero ${ }^{134}$, expressa o "confronto entre dois sistemas filosóficos e ideológicos opostos e suas respectivas concepções sobre razão, história, propriedade e parentesco. Uma é produto de África e outra é uma expressão da modernidade ocidental" ${ }^{135}$. De um lado o patriarcado branco, afiançado na propriedade privada e no casamento, e do outro as famílias negras, que reinventam elementos dos diversos sistemas africanos de parentesco, presentes em estruturas não nucleares de família, nas mães de criação, nas pessoas orfanadas que constituíram comunidades em que todos se chamam de irmãos e irmãs ${ }^{136}$.

127 GONZALEZ, Lélia. Democracia racial? Nada disso! In: GONZALEZ, Lélia. Primavera para rosas negras. São Paulo: UCPA Editora, 2018.

128 WERNECK, Jurema. De ialodês e feministas: reflexões sobre a ação política das mulheres negras na América Latina e Caribe. Nouvelles Questions Féministes, Revue Internationale Francophone, v. 24, n. 2, 2005.

129 OYĚWÙMÍ, Oyèrónké. What gender is motherhood? Changing Yorùbá ideals of power, procreation, and identity in the age of modernity. Londres: Palgrave Mackmillan, 2016.

130 HIGGINBOTHAM, Evelyn Brooks. Righteous discontent: the women's movement in the black baptist church, 1880-1920. Harvard: Harvard University Press, 1993.

131 COLLINS, Patrícia Hill. Pensamento feminista negro: conhecimento, consciência e a política do empoderamento. São Paulo: Boitempo, 2019.

132 PENSAR AFRICANAMENTE. "A pensadora é... Lélia Gonz̧alez”. 2020. 1 vídeo (2h43min.). Disponível em: https://www.youtube.com/watch?v=DW1kZ9yzkI8\&t=2745s. Acesso em: 18 jul. 2020.

133 GONZALEZ, Lélia. A mulher negra na sociedade brasileira. In: GONZALEZ, Lélia. Primavera para rosas negras. São Paulo: UCPA Editora, 2018. p. 37.

134 OYĚWÙMI, Oyèrónké. The invention of women. London: University of Mineapolis Press, 1997.

135 GILROY, Paul. Small acts: thoughts on the politics of black cultures. Londres; Nova York: Serpent's Tail, 1993. p. 177-178.

136 COLLINS, Patrícia Hill. Pensamento feminista negro: conhecimento, consciência e a política do empoderamento. São Paulo: 
Creuza Maria Oliveira, sindicalista do movimento de trabalhadoras domésticas, descreveu assim sua experiência no trabalho doméstico infantil:

Então eu precisava trabalhar, e aquela época eu não tinha casa pra morar, não tinha pai nem mãe [...]. [E]u não tinha pra onde voltar, eu tinha que suportar as várias violências [...]. Era o emprego e acabou, entendeu? [...] Aí eu tava sempre desistindo da escola, porque o mais importante era um lugar pra ficar, a casa ${ }^{137}$.

Nessa história de mulheres abusadas e crianças sequestradas, de ruptura de laços familiares e de traumas repetidos por gerações, o trabalho doméstico tem uma íntima relação com o genocídio ${ }^{138}$, que interdita o que podemos chamar de direito à ancestralidade, originado nas relações de parentesco na linha reta, fundado pelo sangue e/ou pelo afeto, em respeito a todas as formas de família. O direito ao nome, que indica origem, e o direito à busca da ancestralidade, têm proteção constitucional ${ }^{139}$. Compreendido de forma mais ampla, associado à categoria político-cultural de amefricanidade, é uma ferramenta possível de combate ao mito jurídico de impossibilidade da memória da escravidão.

\section{Feminismo negro e imagens de controle: possibilidades para o Direito}

Embora os estudos sobre relações raciais no Brasil tendam a enfatizar o papel da História e da Sociologia como campos disciplinares determinantes tanto no questionamento quanto na legitimação do racismo, o Direito é um espaço de análise potente por seu papel na formação da burocracia estatal e da intelligentsia nacional desde a independência ${ }^{140}$. O papel dos juristas para manutenção de desigualdades raciais no Brasil interpela o que Maria Aparecida Bento chamou de pacto narcísico da branquitude ${ }^{141}$, inclusive entre os setores críticos e progressistas no Brasil e na América Latina, que em geral se recusam a encarar as dinâmicas de poder implicadas em sua própria brancura, bem como o papel central e estruturante da raça nas relações políticas, sociais, econômicas e sexuais que orientam a seletividade do sistema de justiça ${ }^{142}$.

Substituindo o espelho do pacto narcísico, a lagoa de Eco, personagem passiva que reflete as percepções enganosas dos brancos sobre si, como a horda de pessoas que, constrangidas por seu capital social, político e econômico, os aplaudem ${ }^{143}$; buscamos Oxum no espelho constitucional, sem a qual não há vida, que demanda que as mulheres participem das decisões políticas, refletindo a força, o movimento e a maleabilidade das águas ${ }^{144}$. Nesse jogo entre consciência e memória, parafraseando Elisa Lucinda, a Justiça só é possível se passarmos a verdade a limpo e escrevermos juntos, sinceramente, uma outra história ${ }^{145}$, que nos permita o

Boitempo, 2019.

137 OLIVEIRA, Creuza Maria. Entrevista concedida à autora. Brasília, 03 de dezembro de 2019. Em: LOPES, Juliana Araújo. Constitucionalismo brasileiro em pretuguês: trabalhadoras domésticas e lutas por direitos. 2020. Dissertação (Mestrado em Direito) - Universidade de Brasília, Brasília, 2020.

138 RAMOS, Gabriela Batista Pires. "Como se fosse da família": o trabalho doméstico na Assembleia Nacional Constituinte de 1987/1988. Dissertação (Mestrado em Direito) - Universidade Federal da Bahia, Salvador, 2018.

139 BIRCHAL, Alice de Souza. A relação processual dos avós no direito de família: direito à busca da ancestralidade, convivência familiar e alimentos: afeto, ética, família e o Novo Código Civil. Belo Horizonte: Del Rey, 2004.

140 BRITO, Yuri Santos de. "Professora, que bom que você tá aqui": trajetórias e identidades de docentes de Direito da UFBA, UnB e USP no contexto pós-cotas. Dissertação (Mestrado em Sociologia) - Universidade de Brasília, Brasília, 2019.

141 BENTO, Maria Aparecida Silva. Pactos narcísicos no racismo: branquitude e poder nas organizações empresariais e no poder público. Tese (Doutorado em Psicologia) - Universidade de São Paulo, São Paulo, 2002.

142 PIRES, Thula Rafaela de Oliveira. Criminologia crítica e pacto narcísico: por uma crítica criminológica apreensível em pretuguês. Revista Brasileira de Ciências Criminais, São Paulo, v. 135, ano 25, p. 541-562, set. 2017.

143 KILOMBA, Grada. Desobediências poéticas. São Paulo, 2018. Disponível em: http://pinacoteca.org.br/wp-content/uploads/2019/07/AF06_gradakilomba_miolo_baixa.pdf Acesso em: 07 out. 2020.

144 VELECI, Nailah Neves. Cadê Oxum no espelho constitucional? os obstáculos sócio-político-culturais para o combate às violações dos direitos dos povos e comunidades tradicionais de terreiro. 2017. Dissertação (Mestrado em Direitos Humanos) - Universidade de Brasília, Brasília, 2017.

145 LUCINDA, Elisa. Mulata exportação. In: LUCINDA, Elisa. O Semelhante. 3. ed. Rio de Janeiro: Edição do autor, 1997. p. $180-181$. 
reconhecimento e a reparação dos traumas do colonialismo ${ }^{146}$ para sonhar outros futuros possíveis ${ }^{147}$.

Nesse sentido, proponho uma aproximação a partir do pensamento feminista negro, considerando um circuito transnacional de pensadoras que, dentro e fora da academia, produziram contribuições importantes para interrogar lógicas interseccionais de opressão. Os temas clássicos do feminismo negro, a saber, trabalho, família, política sexual, maternidade, relações afetivas, representação e ativismo ${ }^{148}$, oferecem aportes sobre elementos centrais dos desafios atuais que enfrentamos enquanto constitucionalistas em face da crise da democracia brasileira, e nos provocam a formular outras molduras teóricas para compreender a gramática jurídica das lutas por direitos.

A questão da representação tem grande relevo para esta tradição intelectual, que será articulada aqui a partir do conceito de imagens de controle, proposto pela socióloga estadunidense Patricia Hill Collins. A autora as define como um corpo de ideias que reúne estereótipos negativos sobre mulheres negras formulados desde o período colonial que permeiam o imaginário social, com destaque para a mídia e para o discurso acadêmico como locais privilegiados de elaboração e propagação. As imagens de controle descrevem a dimensão ideológica da opressão das mulheres negras, fornecendo legitimidade à sua dimensão econômica e política, justificando a exploração do trabalho precário, a exclusão de espaços institucionais e a negação de direitos ${ }^{149}$.

As imagens de controle não são meramente estereótipos, são mecanismos que distorcem ou dissimulam características existentes de modo a culpar mulheres negras pelas violências que sofrem e por toda sorte de problemas sociais, em vez das desigualdades que lhes dão causa. Ao mesmo tempo, ao retratá-las como objetos, não como sujeitos, sempre na posição do Outro, atuam na supressão de seu pensamento. Confrontá-las consiste num esforço de autodefinição, de forma privada e íntima e/ou pública; como na eloquente afirmação do movimento de domésticas brasileiras na ANC de que não queriam ser da família, mas sim ter direitos e serem reconhecidas enquanto cidadãs e trabalhadoras ${ }^{150}$.

Como um cativeiro do tempo ${ }^{151}$, as imagens de controle nos arrastam de volta para o esquema colonial, registrando simbolicamente "memórias, lendas, piadas, comentários, histórias, mitos, experiências, insultos" nos nossos corpos, nos dizendo como nos portar, com quem falar, aonde ir. "Nos movemos no espaço, em alerta, através desse esquema racial epidérmico" ${ }^{152}$. Articuladas em torno da degeneração da sexualidade e da maternidade de mulheres negras, essas imagens são concebidas em oposição a um modelo ideal de sujeito, de feminilidade ou de família. Portanto, não se pode compreendê-las sem sua contraparte: os homens brancos racionais, as mulheres brancas femininas e a família nuclear branca tradicional ${ }^{153}$.

\footnotetext{
146 KILOMBA, Grada. Memórias da Plantação: episódios de racismo cotidiano. Rio de Janeiro: Cobogó, 2019.

147 Esse papo de mães-útero pode soar muito hetero-cisnormativo, embora Iyá não seja uma instituição generificada. OYĚWÙMÍ, Oyèrónké. The invention of women. London: University of Mineapolis Press, 1997. Lembrando a "mulata exportação" de Lucinda, se fomos definidas como objetos sexuais, como parideiras compulsórias, estupradas pra mover as engrenagens do capitalismo; a autodefinição também reside em recobrar nosso poder erótico. LORDE, Audre. Os usos do erótico. In: LORDE, Audre. Irmã outsider. ensaios e conferências. Belo Horizonte: Autêntica Editora, 2019.

148 COLLINS, Patrícia Hill. Pensamento feminista negro: conhecimento, consciência e a política do empoderamento. São Paulo: Boitempo, 2019.

149 COLLINS, Patrícia Hill. Pensamento feminista negro: conhecimento, consciência e a política do empoderamento. São Paulo: Boitempo, 2019.

150 COLLINS, Patrícia Hill. Pensamento feminista negro: conhecimento, consciência e a política do empoderamento. São Paulo: Boitempo, 2019.

151 GOMES, Rodrigo Portela; OLIVEIRA, Emília Joana Viana de. Cativeiros do tempo: a política do tempo sob as comunidades quilombolas. In: CONGRESSO INTERNACIONAL CONSTITUCIONALISMO E DEMOCRACIA, 6., 2016, Rio de Janeiro. Anais [...] Rio de Janeiro: UFRJ, 2016. p. 244-262.

152 Aqui, Grada Kilomba refere-se ao esquema racial epidérmico formulado pelo psicanalista e filósofo martinicano Frantz Fanon. KILOMBA, Grada. Memórias da Plantação: episódios de racismo cotidiano. Rio de Janeiro: Cobogó, 2019. p. 175. FANON, Frantz. Pele negra, máscaras brancas. Salvador: EDUFBA, 2008.

153 COLLINS, Patrícia Hill. Pensamento feminista negro: conhecimento, consciência e a política do empoderamento. São Paulo: Boitempo, 2019.
} 
Considerando que o pensamento moderno, embora se apresente como registro do pensamento racional, abstrato, que tem as ideias como sujeitos da História, é orientado pelo corpo, o que Oyèrónké Oyènùmí chamou de bio-lógica, ou somatocentricidade. A diferença, que organiza o mundo em pares binários antitéticos, é expressa como degeneração física e moral de um tipo original e superior da biologia, a dos homens brancos europeus, tendo a visão como sentido privilegiado de apreensão do mundo. A cor da pele e a genitália, por exemplo, demarcam a diferença racial e sexual no corpo, e encerram os Outros no domínio da natureza e da emoção, enquanto o Ser, quem lança o olhar colonial, é o sujeito pretensamente racional e universal. Nesse sentido, o biológico e o social se retroalimentam ${ }^{154}$.

As imagens de controle podem e devem ser mobilizadas como ferramentas analíticas para a promoção de justiça social no Direito brasileiro ${ }^{155}$, como já vem sendo feito por intelectuais negras em outras partes do mundo. A jurista estadunidense Dorothy Roberts demonstra a força dessas imagens na produção de legislação e políticas públicas. Considerando o papel central da sexualidade e da maternidade como norteadoras dessas políticas, as imagens de controle indicam que embora as teorias do racismo científico não estejam mais em voga, a raça ainda opera como um traço biológico. Indicam ainda que o funcionamento do racismo de Estado tem no controle reprodutivo de mulheres negras uma chave que não pode ser ignorada ${ }^{156}$. Vale lembrar que o caso paradigmático de racismo institucional no Brasil é o de Aline Pimentel, gestante negra que entrou para as estatísticas de mortalidade materna no SUS, que resultou na condenação do Brasil pelo Comitê pela Eliminação de Todas as Formas de Discriminação Contra a Mulher - CEDAW em agosto de $2011^{157}$.

Os exemplos clássicos de imagens de controle são a Jezebel, piranha promíscua e agressiva que justifica a violência sexual, a rainha da assistência social, encostada em benefícios assistenciais do Estado que tem vários filhos para não ter que trabalhar, a matriarca, mãe trabalhadora bruta e ausente culpada pela pobreza de sua família e pela emasculação de seus homens, além da mammy ou mãe preta, a escrava doméstica leal e obediente que existe para servir ${ }^{158}$. Elas cristalizam mulheres negras em papeis fixos definidos pela criminalidade, pela imoralidade, pela preguiça, pelo abandono e pela incapacidade de fechar as pernas, que registram desvios da disciplina do trabalho esperada de uma boa escrava e justificam a necessidade de regulação compulsória do Estado e a remoção de seus filhos. As crianças herdam seus traços desviantes, por isso devem igualmente ser criminalizadas ${ }^{159}$. A única representação ideal de mulheres negras no imaginário racista é, evidentemente, a mãe preta, "a cuidadora passiva, a figura materna que dava tudo sem expectativa de retorno, que não só reconhecia sua inferioridade aos brancos, mas que os amava"160, que "não tinha autoridade real nem sobre as crianças brancas que criava nem sobre as crianças negras que paria"161.

Estas representações foram exaustivamente acionadas na Assembleia Nacional Constituinte de 1987/1988. As domésticas foram lembradas como as meninas com quem os coronéis latifundiários iniciavam suas vidas sexuais; como aquelas adotadas informalmente para servirem como domésticas; como beneficiárias da previdência social, enquanto a "dona de casa grã-fina" não teria proteção nenhuma; como as mães das meninas infratoras "presas” na FUNABEM - Fundação Nacional do Bem Estar do Menor; como as mulheres que abortam e vão presas ou morrem; como as crianças que abandonam a escola para trazer um

154 OYĚWÙMÍ, Oyèrónké. The invention of women. London: University of Mineapolis Press, 1997.

155 BUENO, Winnie. Imagens de controle: um conceito do pensamento de Patricia Hill Collins. Porto Alegre: Zouk Editora, 2020.

156 ROBERTS, Dorothy. Killing the Black Body: race, reproduction, and the meaning of liberty. New York: Vintage Books, 2017. Tradução livre.

157 CONCEIÇÃO, Isis Aparecida. Justiça racial e a teoria crítica racial no Brasil: uma proposta de teoria geral. In: AUAD, D; OLIVEIRA, B. (org.). Direitos humanos, democracia e justiça social: uma homenagem à Professora Eunice Prudente: da militância à academia. São Paulo: Letras Jurídicas, 2017. p. 167-204.

158 COLLINS, Patrícia Hill. Pensamento feminista negro: conhecimento, consciência e a política do empoderamento. São Paulo: Boitempo, 2019.

159 ROBERTS, Dorothy. Killing the Black Body: race, reproduction, and the meaning of liberty. New York: Vintage Books, 2017. Tradução livre.

160 HOOKS, Bell. E eu não sou uma mulher? Mulheres negras e feminismo. Rio de Janeiro: Rosa dos Tempos, 2019.

161 ROBERTS, Dorothy. Killing the Black Body: race, reproduction, and the meaning of liberty. New York: Vintage Books, 2017. Tradução livre. p. 13. 
dinheirinho a suas famílias, que sofrem violência em casa e eventualmente vão parar na rua, perdendo seus vínculos familiares; como parte do trabalho de base do movimento negro no início do século, na forma da Frente Negra e da imprensa negra paulista, cujos militantes as instruíam a responder às patroas ${ }^{162}$.

Florestan Fernandes, sociólogo e deputado constituinte pelo PT/SP, falou do papel das mulheres negras como trabalhadoras domésticas em sua avaliação da integração do negro na sociedade brasileira no período pós-abolição na Subcomissão dos Negros, Populações Indígenas, Pessoas Deficientes e Minorias. Neste processo, o homem negro teria passado a repudiar o trabalho e supostamente "não queria trabalhar" porque "achava que as formas de trabalho estavam associadas a modalidades de degradação humana que eram comparáveis àquelas que se produziram sob a escravidão". Enquanto isso, para a mulher negra, livre das restrições impostas aos homens negros, acostumada à relação com o branco no emprego doméstico, sem a proteção que impedia as brancas de acessarem o mercado de trabalho, a crise teria sido menor, uma vez que elas tinham condições de trabalhar ${ }^{163}$.

Na mesma comissão, Lélia Gonzalez fez uma longa exposição sobre a importância do processo constituinte para a população negra, compreendido como uma grande oportunidade de produzir um projeto de nação que não se resumisse ao projeto da minoria dominante que escreve a história oficial do Brasil. Considerando o papel da ideologia da alienação que silencia e marginaliza as contribuições do negro para a sociedade, sua fala voltou-se para as representações hegemônicas do mito da democracia racial na cultura brasileira, identificando o papel fundamental da mídia de massa e das instituições de ensino em sua reprodução, que reiteram nossas imagens como criminosos e prostitutas.

Lélia lembrou o projeto de embranquecimento que o Brasil adotou no período pós-abolição, consubstanciado no estímulo à imigração europeia e proibição de entrada de imigrantes não brancos, o que promoveria a transformação física do povo brasileiro, orientada por teorias evolucionistas; e ressaltou o papel da mulher negra explorada pelo senhor/patrão, que africanizou o português falado no Brasil. O estupro destas mulheres foi lembrado como evidência de que a democracia racial é uma mentira. Lélia compreendia o racismo como um obstáculo à efetivação da democracia, expresso no discurso trabalhista nacional por meio do paternalismo, inclusive pelas esquerdas.

Chega desta postura paternalista que marca todas as relações da sociedade brasileira, as relações dos donos do poder com relação aos explorados, oprimidos e aos dominados; relações de compadrio, relações pessoais.

Sabemos, perfeitamente, o espanto que caracteriza esses senhores do poder, seja ele político, econômico, quando por exemplo, o trabalhador brasileiro se organiza e faz uma greve. É um espanto: "Afinal somos tão bons, por quêe estão farendo greve"? [...]

Sabemos as origens desse mito da democracia racial. Ele tem a ver com a desmobilização do negro que se organiza nos anos 10, 20, 30 explodindo na Frente Negra Brasileira. Vemos o Sr. Getúlio Vargas apropriando-se dessa muito bem elaborada ideologia, pelo mui digno representante das elites açucareiras deste País, e se apresentou para a população negra como pai. $\mathrm{O}$ famoso discurso da democracia racial desmobiliza, inclusive, as esquerdas, que embarcam num discurso de direita, porque, transpondo mecanicamente a questão da luta de classe para a sociedade brasileira, [...] o que vamos perceber? As esquerdas embarcam no velho discurso da democracia racial brasileira e não atentam para o fato de que a maior parte dos trabalhadores brasileiros é constituída por negros e não atentam para essa contradição que marca as relações de nossa sociedade.

Diante disto, nós, negros, tivemos que ir à luta, praticamente, sozinhos e sobretudo nos anos 70, inspirados muito pela nossa própria história, pela nossa história de resistência, de postura democrática já em Palmares, no século XVII, democrática do ponto de vista racial. Partindo para nos organizar e vamos ter, nos anos 70 , todo o renascer do movimento negro na nossa sociedade, inspirado efetivamente nas lutas de libertação da África, sobretudo a África lusófona. Inspirado na luta pelos direitos civis nos Estados Unidos, mas,

162 LOPES, Juliana Araújo. Constitucionalismo brasileiro em pretuguês: trabalhadoras domésticas e lutas por direitos. 2020. Dissertação (Mestrado em Direito) - Universidade de Brasília, Brasília, 2020.

163 BRASIL. Senado Federal. Atas da Subcomissão dos Negros, Populações Indígenas, Pessoas Deficientes e Minorias. Brasília: Senado Federal, 1987. Disponível em: https://www.senado.leg.br/publicacoes/anais/asp/CT_Abertura.asp. Acesso em: 01 dez. 2019. 
fundamentalmente, apoiados, rastreados, em cima da nossa própria história de resistência e de luta. Os nomes de Zumbi e de Palmares, Revolta dos Malês, os nomes de [Luiza Mahin], de Dandara, a Revolta das Chibatas, dentro já do esquema da República positivista.

[...] E neste momento em que aqui estamos, para discutir a questão da Constituinte, [...] sem o criouléu, sem os negros, não se construirá uma Nação neste País! [grifos meus] ${ }^{164}$.

Esta fala foi seguida de falas deputados que "mamaram em preta" e percebem que permaneceram resquícios de preconceito camuflados. Alcenir Guerra (PFL/PR) discordou da expoente porque identificou na plateia "uma mulher branca bonita e duas negras extremamente bonitas". Nascido no Rio Grande do Sul, o deputado e relator da Subcomissão narrou que viu uma pessoa preta pela primeira vez aos sete anos e teve muito medo, mas depois tornou-se amigo de seus filhos. Ressaltou ainda que em sua geração não havia quem não tivesse amado uma negra, citando amigos que se relacionavam com mulheres negras, e enumerando diversas pessoas negras que conhecia como prova de que não tinha preconceito. Ao final, disse que a colega constituinte Benedita da Silva (PT/RJ) era um exemplo de simpatia e extroversão, querida por todos os parlamentares ${ }^{165}$.

Este imaginário em disputa foi determinante para a negação de direitos das trabalhadoras domésticas durante a ANC. Gabriela Ramos destaca o papel do discurso paternalista na Comissão de Sistematização, responsável por remover uma série de direitos fundamentais demandados pela categoria que estavam na redação que passou pela fase popular. A supressão da proibição do trabalho do menor a pretexto de educação e criação foi justificada pela Emenda 1P00812-3, de Inocêncio Oliveira (PFL/PE), que argumentava que a proibição seria utópica, uma vez que "É mais comum do que se pode imaginar o fato de menores afilhados e protegidos da família, especialmente do interior, hospedem-se com uma família realizem tarefas domésticas. Proibir este fato é inviabilizar a vida futura de um grande número de brasileiros”, e pela Emenda 1P151031 de Bernardo Cabral (PMDB/AM), que entendia que a gratuidade do trabalho nem sempre caracteriza exploração, "se constituindo muitas vezes, numa oportunidade de ajuda da família hospedeira a pessoas necessitadas que, em troca, recebem alimentação, moradia, amparo à saúde e à educação"166.

\section{Considerações finais}

Se os direitos fundamentais são uma abertura para o passado, a porta de entrada para a história no sistema jurídico ${ }^{167}$, frágeis conquistas discursivas em processo permanente de mutação e disputa, e, portanto, sujeitas ao risco de abuso e retrocesso ${ }^{168}$, a história do trabalho doméstico e da organização associativo-sindical da categoria tem muito a nos ensinar sobre a longa e tortuosa trajetória de construção da democracia no Brasil e no mundo, e sobre a possibilidade um horizonte ético e político livre de racismo e sexismo. Para Creuza Oliveira, a organização do movimento de trabalhadoras domésticas em Salvador a partir dos anos 1970 foi "uma luz no fundo do túnel, que eu nunca tinha ouvido ninguém dizer que ia defender doméstica, era a primeira vez que eu estava ouvindo alguém dizer que ia defender doméstica", a possibilidade de uma vida sem violência para ela e sua categoria que passava pelo reconhecimento do valor social de seu trabalho, do qual muitas tinham vergonha ${ }^{169}$.

\footnotetext{
164 BRASIL. Senado Federal. Atas da Subcomissão dos Negros, Populações Indígenas, Pessoas Deficientes e Minorias. Brasília: Senado Federal, 1987. Disponível em: https://www.senado.leg.br/publicacoes/anais/asp/CT_Abertura.asp. Acesso em: 01 dez. 2019.

165 BRASIL. Senado Federal. Atas da Subcomissão dos Negros, Populações Indígenas, Pessoas Deficientes e Minorias. Brasília: Senado Federal, 1987. Disponível em: https://www.senado.leg.br/publicacoes/anais/asp/CT_Abertura.asp. Acesso em: 01 dez. 2019.

166 RAMOS, Gabriela Batista Pires. "Como se fosse da família": o trabalho doméstico na Assembleia Nacional Constituinte de 1987/1988. Dissertação (Mestrado em Direito) - Universidade Federal da Bahia, Salvador, 2018. p. 92-93.

167 QUEIROZ, Marcos Vinícius Lustosa. Direitos Fundamentais como Abertura para o Passado: apontamentos para a teoria e a história constitucional a partir do pós-colonial. 2018. No prelo.

168 CARVALHO NETTO, M. de; SCOTTI, G. Os direitos fundamentais e a (in)certeza do direito a produtividade das tensões principiológicas e a superação do sistema de regras. Belo Horizonte: Fórum, 2011. v. 1.

169 OLIVEIRA, Creuza Maria. Entrevista concedida à autora. Brasília, 03 de dezembro de 2019. Em: LOPES, Juliana Araújo.
} 
Nem sempre a liberdade tem a forma da luta de vida e morte entre senhor e escravo, mas de um percurso menos solitário e de menor amplitude geográfica que o dos homens, buscando autodefinição na conexão entre indivíduos, não na oposição, transformando silêncio em linguagem e ação. Na dupla consciência desenvolvida pelas trabalhadoras domésticas na casa dos patrões, negociando as imagens do opressor sobre si com "um ponto de vista autodefinido" protegido "dos olhos curiosos dos grupos dominantes", escondiam orgulho e resistência sob a máscara de aparente conformidade ${ }^{170}$.

E aí o MNU, e mais os cursos de formação [das mulheres da CUT e do SOS Corpo, ONG feminista de Pernambuco] que a gente teve com o grupo de doméstica, que eu saía de Salvador pra Recife sem minha patroa saber. Eu saía dia de sábado de Salvador, chegava domingo de manhã em Recife, participava de um curso de formação, que era onde a gente trabalhava nossa autoestima ${ }^{171}$.

A ruptura das imagens de controle internalizadas, que a faziam se achar "a pessoa mais feia do mundo", que "não conseguia [se] olhar no espelho" ${ }^{172}$, passaram por um processo coletivo de formação política e reconstrução da autoestima, que possibilitavam o empoderamento para a luta política; um investimento que não é comum nas formas do sindicalismo tradicional, hegemonicamente masculino e branco. Lenira de Carvalho identifica o problema da solidão como uma questão no início da organização da categoria em Recife/ PE na década de 1960, que posteriormente se destacou de espaços compartilhados com outros trabalhadores para discutirem suas questões específicas. Para aquelas que moravam no emprego, a calçada era um dos primeiros espaços de socialização, uma vez que não podiam levar visitas para a casa da patroa. A associação se tornaria, assim, um espaço de atividades não só políticas, mas sociais ${ }^{173}$.

A doméstica não tem muito com quem conversar no emprego. Prefere ficar calada, por há patroas que julgam que entre a cozinheira e a porta da cozinha a diferença é que a primeira se move. Por isso, quando a gente se encontra, custa pôr o papo em dia. [...]

De vez em quando, nos domingos, começamos a reunir as domésticas somente para nos distrairmos. Comemorávamos aniversários, convidávamos alguns rapazes (para também podermos dançar) e fazíamos algumas brincadeiras. Chamávamos esses momentos de "Tarde Alegre"174.

A conversão das associações em sindicatos com a Constituição de 1988 inaugurou um novo momento de possibilidades ampliadas de representação política, dando mais visibilidade à categoria no cenário nacional. A luta por direitos transcende os limites das demandas da carta apresentada à Assembleia Nacional Constituinte no dia 5 de maio de 1987.

Porque se a gente tá lutando por igualdade, por equiparação de direito, e aí não é só direito trabalhista, é o direito de participação sindical, [...] é o direito de moradia, é o direito à saúde, é o direito de participação política $^{175}$.

Constitucionalismo brasileiro em pretuguês: trabalhadoras domésticas e lutas por direitos. 2020. Dissertação (Mestrado em Direito) - Universidade de Brasília, Brasília, 2020.

170 COLLINS, Patrícia Hill. Pensamento feminista negro: conhecimento, consciência e a política do empoderamento. São Paulo: Boitempo, 2019. p. 180.

171 OLIVEIRA, Creuza Maria. Entrevista concedida à autora. Brasília, 03 de dezembro de 2019. Em: LOPES, Juliana Araújo. Constitucionalismo brasileiro em pretuguês: trabalhadoras domésticas e lutas por direitos. 2020. Dissertação (Mestrado em Direito) - Universidade de Brasília, Brasília, 2020.

172 OLIVEIRA, Creuza Maria. Entrevista concedida à autora. Brasília, 03 de dezembro de 2019. Em: LOPES, Juliana Araújo. Constitucionalismo brasileiro em pretuguês: trabalhadoras domésticas e lutas por direitos. 2020. Dissertação (Mestrado em Direito) - Universidade de Brasília, Brasília, 2020.

173 RONCADOR, Sônia. Escritoras de Avental: notas sobre o testemunho de uma doméstica. Revista de Letras UNESP, São Paulo, v. 44, n. 2, p. 163-187, 2004.

174 RONCADOR, Sônia. Escritoras de Avental: notas sobre o testemunho de uma doméstica. Revista de Letras UNESP, São Paulo, v. 44, n. 2, p. 163-187, 2004. p. 181-182.

175 OLIVEIRA, Creuza Maria. Entrevista concedida à autora. Brasília, 03 de dezembro de 2019. Em: LOPES, Juliana Araújo. Constitucionalismo brasileiro em pretuguês: trabalhadoras domésticas e lutas por direitos. 2020. Dissertação (Mestrado em Direito) - Universidade de Brasília, Brasília, 2020. 
Ela se refere à dimensões existências da vida de milhares de mulheres atravessadas por cinco séculos de violência colonial, que, no limite, provocam a sociedade brasileira a reconhece-las como pessoas, cidadãs, sujeitos ativos na esfera pública, tão humanas quanto qualquer um.

\section{Referências}

ALBERTO, Paulina. Terms of inclusion: black intellectuals in twentieth-century Brazil. North Carolina: The University of North Carolina Press, 2011.

ALVES, Raissa Roussenq. Entre o silêncio e a negação: trabalho escravo contemporâneo sob a ótica da população negra. Belo Horizonte: Letramento, 2019.

BARRETO, Raquel. Lélia Gonzalez: uma intérprete do Brasil. In: GONZALEZ, Lélia. Primavera para as rosas negras: Lélia Gonzalez em primeira pessoa. São Paulo: Diáspora Africana, 2018.

BENTO, Maria Aparecida Silva. Pactos narcísicos no racismo: branquitude e poder nas organizações empresariais e no poder público. Tese (Doutorado em Psicologia) - Universidade de São Paulo, São Paulo, 2002.

BERNARDINO-COSTA, Joaze. Sindicatos das trabalhadoras domésticas no Brasil: teorias de descolonização e saberes subalternos. 2007. Tese (Doutorado em Sociologia) - Universidade de Brasília, Brasília, 2007.

BERTÚLIO, Dora Lúcia de Lima. Direito e relaçoes raciais: uma introdução crítica ao racismo. Rio de Janeiro: Lúmen Juris, 2019.

BIRCHAL, Alice de Souza. A relação processual dos avós no direito de família: direito à busca da ancestralidade, convivência familiar e alimentos: afeto, ética, família e o Novo Código Civil. Belo Horizonte: Del Rey, 2004.

BLOGUEIRAS NEGRAS. Crenza Oliveira em Mulheres na Conapir. 2013. 1 vídeo (47 min.) Disponível em: https://www.youtube.com/watch?v=CjG4zfPomoM. Acesso em: 30 jun. 2019.

BRANDÃO, Isadora. Da invisibilização ao reconhecimento institucional. Belo Horizonte: Letramento, 2019.

BRASIL. Senado Federal. Atas da Subcomissão dos Direitos dos Trabalhadores e Servidores Públicos. Brasília: Senado Federal, 1987. Disponível em: https://www.senado.leg.br/publicacoes/anais/asp/CT_Abertura.asp. Acesso em: 01 dez. 2019.

BRASIL. Senado Federal. Atas da Subcomissão dos Negros, Populacõoes Indígenas, Pessoas Deficientes e Minorias. Brasília: Senado Federal, 1987. Disponível em: https://www.senado.leg.br/publicacoes/anais/asp/CT_ Abertura.asp. Acesso em: 01 dez. 2019.

BRITES, Jurema Gorski. Trabalho doméstico: questões, leituras e políticas. Cadernos de Pesquisa, São Paulo, v. 43, n. 149, p. 422-451, ago. 2013. Disponível em: http://www.scielo.br/scielo.php?script=sci_ arttext\&pid=S0100-15742013000200004\&lng=pt\&nrm=iso. Acesso em: 23 out. 2017.

BRITO, Yuri Santos de. "Professora, que bom que você tá aqui": trajetórias e identidades de docentes de Direito da UFBA, UnB e USP no contexto pós-cotas. Dissertação (Mestrado em Sociologia) - Universidade de Brasília, Brasilia, 2019.

BUENO, Winnie. Imagens de controle: um conceito do pensamento de Patricia Hill Collins. Porto Alegre: Zouk Editora, 2020.

CARNEIRO, Sueli. A construção do outro como não-ser como fundamento do ser. 2005. Tese (Doutorado em Educação) - Universidade de São Paulo, São Paulo, 2005.

CARNEIRO, Sueli. Lélia Gonzalez: o feminismo negro no palco da história. Brasília: Abravídeo, 2014.

CARVALHO NETTO, M. de; SCOTTI, G. Os direitos fundamentais e a (in)certeza do direito a produtividade das 
tensões principiológicas e a superação do sistema de regras. Belo Horizonte: Fórum, 2011. v. 1.

COLLINS, Patrícia Hill. Pensamento feminista negro: conhecimento, consciência e a política do empoderamento. São Paulo: Boitempo, 2019.

CONCEIÇÃO, Isis Aparecida. Justiça racial e a teoria crítica racial no Brasil: uma proposta de teoria geral. In: AUAD, D; OLIVEIRA, B. (org.). Direitos humanos, democracia e justiça social: uma homenagem à Professora Eunice Prudente: da militância à academia. São Paulo: Letras Jurídicas, 2017. p. 167-204.

CRENSHAW, Kimberlé. Respect. In: ENSLER, Eve. The Vagina Monologues. EUA: Virago, 2002.

DAVIS, Angela. Mulheres, Raça e Classe. São Paulo: Boitempo, 2016.

DUARTE, Evandro Piza; SCOTTI, Guilherme. História e memória nacional no discurso jurídico: o julgamento da ADPF 186. Universitas JUS, Brasília, v. 24, n. 3, p. 33-45, 2013. Disponível em: https://www. publicacoesacademicas.uniceub.br/jus/article/view/2611 Acesso em: 15 ago. 2019.

DUARTE, Evandro Piza; SCOTTI, Guilherme; CARVALHO NETO, Menelick de. Ruy Barbosa e a queima dos arquivos: as lutas pela memória da escravidão e os discursos dos juristas. Universitas JUS, Brasília, v. 26, n. 2, p. 23-39, 2015. Disponível em: https://www.publicacoesacademicas.uniceub.br/jus/article/view/3553 Acesso em: 23 abr. 2020.

FANON, Frantz. Pele negra, máscaras brancas. Salvador: EDUFBA, 2008.

FEDERICI, Silvia. O Calibã e a bruxa: mulheres, corpo e acumulação primitiva. São Paulo: Elefante, 2018.

FLAUZINA, Ana Luiza Pinheiro. Democracia genocida. In: PINHEIRO-MACHADO, Rosana; FREIXO, Adriano de (org.). Brasil em transe: Bolsonarismo, nova direita e desdemocratização. Rio de Janeiro: Oficina Raquel, 2019.

FLAUZINA, Ana Luiza Pinheiro. Prefácio. In: BRANDÃO, Isadora. Da invisibilização ao reconhecimento institucional. Belo Horizonte: Letramento, 2019.

FLAUZINA, Ana Luiza Pinheiro; FREITAS, Felipe da Silva. Do paradoxal privilégio de ser vítima: terror de Estado e a negação do sofrimento negro no Brasil. Revista Brasileira de Ciências Criminais, São Paulo, ano 25, v. 135, p. 49-71, set. 2017.

FREYRE, Gilberto. Casa grande \& senzala. Rio de Janeiro: Record, 2017.

GARGARELLA, Roberto. Latin american constitutionalism: social rights and the "engine room" of the constitution. Notre Dame Journal of International \& Comparative Law, v. 4, n. 1, 2014.

GILROY, Paul. O Atlântico negro: modernidade e dupla consciência. São Paulo: Editora 34; Rio de Janeiro: Universidade Candido Mendes, Centro de Estudos Afro-Asiáticos, 2012.

GOMES, Rodrigo Portela; OLIVEIRA, Emília Joana Viana de. Cativeiros do tempo: a política do tempo sob as comunidades quilombolas. In: CONGRESSO INTERNACIONAL CONSTITUCIONALISMO E DEMOCRACIA, 6., 2016, Rio de Janeiro. Anais [...] Rio de Janeiro: UFRJ, 2016. p. 244-262.

GONZALEZ, Lélia. A categoria político-cultural de amefricanidade. Tempo Brasileiro, Rio de Janeiro, n. 92/93, p. 69-82, jan./jun. 1988.

GONZALEZ, Lélia. A mulher negra na sociedade brasileira. In: GONZALEZ, Lélia. Primavera para rosas negras. São Paulo: UCPA Editora, 2018.

GONZALEZ, Lélia. Democracia racial? Nada disso! In: GONZALEZ, Lélia. Primavera para rosas negras. São Paulo: UCPA Editora, 2018.

GONZALEZ, Lélia. Por um feminismo afrolatinoamericano. In: GONZALEZ, Lélia. Primavera para rosas negras. São Paulo: UCPA Editora, 2018. p. 307-320. 
GONZALEZ, Lélia. Racismo e sexismo na cultura brasileira. Revista Ciências Sociais Hoje - Anpocs, p. 223-244, 1984.

GRAHAM, Sandra Lauderdale. House and street: the domestic world of servants and masters in nineteenthcentury. Cambridge: Cambridge University Press, 1988.

HARRIS, Cheryl I. Whiteness as property. Harvard Law Review, v. 106, n. 8, jun. 1993.

HARTMAN, Saidiya. Lose your mother: a journey along the Atlantic slave rout. New York: Farrar, Straus and Giroux, 2008.

HARTMAN, Saidiya. The belly of the world: a note on Black women's labor. Souls: A Critical Journal of Black Politics, Culture, and Society, v. 18, n. 1, p. 166-173, 2016.

HIGGINBOTHAM, Evelyn Brooks. Righteous discontent: the women's movement in the black baptist church, 1880-1920. Harvard: Harvard University Press, 1993.

HOOKS, Bell. E en não sou uma mulher? Mulheres negras e feminismo. Rio de Janeiro: Rosa dos Tempos, 2019.

KILOMBA, Grada. Desobediências poéticas. São Paulo, 2018. Disponível em: http://pinacoteca.org.br/wpcontent/uploads/2019/07/AF06_gradakilomba_miolo_baixa.pdf Acesso em: 07 out. 2020.

KILOMBA, Grada. Memórias da Plantação: episódios de racismo cotidiano. Rio de Janeiro: Cobogó, 2019.

LOPES, Juliana Araújo. Constitucionalismo brasileiro em pretuguês: trabalhadoras domésticas e lutas por direitos. 2020. Dissertação (Mestrado em Direito) - Universidade de Brasília, Brasília, 2020.

LORDE, Audre. A transformação do silêncio em linguagem e ação. In: LORDE, Audre. Irmã outsider: ensaios e conferências. Belo Horizonte: Autêntica Editora, 2019.

LORDE, Audre. As ferramentas do senhor nunca derrubarão a casa grande. In: LORDE, Audre. Irmã outsider: ensaios e conferências. Belo Horizonte: Autêntica Editora, 2019.

LORDE, Audre. Os usos do erótico. In: LORDE, Audre. Irmã outsider: ensaios e conferências. Belo Horizonte: Autêntica Editora, 2019.

LUCINDA, Elisa. Mulata exportação. In: LUCINDA, Elisa. O Semelhante. 3. ed. Rio de Janeiro: Edição do autor, 1997.

MACHADO, Taís Sant'Anna. Paralelos entre a mãe-preta brasileira e a mammy estadunidense? Sobre a identidade, culinária, raça e diáspora negra. In: JORNADA DE ESTUDOS NEGROS DA UNB, 1., 2016, Brasília. Anais [.... Brasília: UnB, 2016, p. 119-137.

MBEMBE, Achille. Politicas da inimizade. Lisboa: Antígona, 2017.

MILLS, Charles. The Racial Contract. Nova York: Cornell University, 1997.

MUNANGA, Kabengele. Rediscutindo a mestiçagem no Brasil. Belo Horizonte: Autentica Editora, 2004.

NASCIMENTO, Beatriz. Beatriz Nascimento: quilombola e intelectual. São Paulo: Filhos da África, 2018.

NASCIMENTO, Guilherme; DUARTE, Evandro; QUEIROZ, Marcos. O silêncio dos juristas: a imunidade tributária sobre templo de qualquer culto e as religiões de matriz africana à luz da constituição de 1988. Revista Quaestio Iuris, Rio de Janeiro, v. 10, n. 2, p. 1162-1180, 2017.

NERIS, Natália. A voz e a palavra do movimento negro na Constituinte de 1988. São Paulo: Casa do Direito, 2018.

NUCCI, Guilherme de Souza. Manual de Direito Penal. 10. ed. Rio de Janeiro: Forense, 2014.

OKIN, Susan Moller. Justice, Gender and the Family. In: BAILEY, A. et al. The Broadview anthology of social and political thought. essential readings. Peterborough: Broadview Press, 2012. 
OLIVEIRA, Adriana Vidal de. A constituição da mulher brasileira: uma análise dos estereótipos de gênero na Assembleia Constituinte de 1987-1988 e suas consequências no texto constitucional. 2012. Tese (Doutorado em Direito) - PUC-Rio, Rio de Janeiro, 2012.

OYĚWÙMÍ, Oyèrónké. The invention of women. London: University of Mineapolis Press, 1997.

OYĚWÙMÍ, Oyèrónké. What gender is motherhood? Changing Yorùbá ideals of power, procreation, and identity in the age of modernity. Londres: Palgrave Mackmillan, 2016.

PENSAR AFRICANAMENTE. “A pensadora é... Lélia Gonzalez”. 2020. 1 vídeo (2h43min.). Disponível em: https:/ /www.youtube.com/watch?v=DW1kZ9yzkI8\&t=2745s. Acesso em: 18 jul. 2020.

PINTO, Elisabete Aparecida. Etnicidade, gênero e educação: trajetória de vida de Laudelina de Campos Mello. São Paulo: Anita Garibaldi, 2015.

PIRES, Thula Rafaela de Oliveira. Colorindo memórias e redefinindo olhares: ditadura militar e racismo no Rio de Janeiro. 2015. Disponível em: https:/ /observatoriosc.org.br/noticia/colorindo-memorias-e-redefinindoolhares-ditadura-militar-e-racismo-no-rio-de-janeiro/ Acesso em: 7 out. 2020.

PIRES, Thula Rafaela de Oliveira. Criminologia crítica e pacto narcísico: por uma crítica criminológica apreensível em pretuguês. Revista Brasileira de Ciências Criminais, São Paulo, v. 135, ano 25, p. 541-562, set. 2017.

PIRES, Thula. Por um constitucionalismo ladinoamefricano. In: BERNARDINO-COSTA, Joaze; MALDONADO-TORRES, Nelson; GROSGOGUEL, Ramon (orgs.). Decolonialidade e pensamento afrodiaspórico. Belo Horizonte: Autêntica Editora, 2018.

PRETA-RARA. Eu, empregada doméstica: a senzala moderna é o quartinho da empregada. Belo Horizonte: Letramento, 2019.

QUEIROZ, Marcos Vinícius Lustosa. Constitucionalismo brasileiro e o Atlântico Negro: a experiência constitucional de 1823 diante da Revolução Haitiana. Rio de Janeiro: Lúmen Juris, 2018.

QUEIROZ, Marcos Vinícius Lustosa. Direitos Fundamentais como Abertura para o Passado: apontamentos para a teoria e a história constitucional a partir do pós-colonial. 2018. No prelo.

RAMOS, Gabriela Batista Pires. "Como se fosse da família”: o trabalho doméstico na Assembleia Nacional Constituinte de 1987/1988. Dissertação (Mestrado em Direito) - Universidade Federal da Bahia, Salvador, 2018.

RIOS, Flávia Mateus. Elite Política Negra no Brasil: relação entre movimento social, partidos políticos e Estado. Tese (Doutorado em Sociologia) - Universidade de São Paulo, São Paulo, 2014.

ROBERTS, Dorothy. Killing the Black Body: race, reproduction, and the meaning of liberty. New York: Vintage Books, 2017.

RONCADOR, Sônia. A doméstica imaginária: literatura, testemunhos e a invenção da empregada doméstica no Brasil (1889-1999). Brasília: Universidade de Brasília, 2008.

RONCADOR, Sônia. Escritoras de Avental: notas sobre o testemunho de uma doméstica. Revista de Letras UNESP, São Paulo, v. 44, n. 2, p. 163-187, 2004.

SANTOS, Martha M. "Slave Mothers", Partus Sequitur Ventrem, and the Naturalization of Slave Reproduction in Nineteenth-Century Brazil. Tempo Niterói, v. 22, n. 41, p. 467-484, set./dez. 2016. Disponível em: https://www.scielo.br/scielo.php?script=sci_arttext\&pid=S1413-77042016000300467. Acesso em: 22 maio 2020.

SILVA, Denise Ferreira da. À brasileira: racialidade e a escrita de um desejo destrutivo. Rev. Estud. Fem., Florianópolis, v. 14, n. 1, p. 61-83, abr. 2006. Disponível em: http://www.scielo.br/scielo.php?script=sci_ arttext\&pid=S0104-026X2006000100005\&lng=en\&nrm=iso. Acesso em: 23 nov. 2017. 
SILVA, Fernanda Lima da. Dançar em praça de guerra: precariedade e liberdade na cidade negra (Recife, 1870-1888). 2019. Dissertação (Mestrado em Direito) - Universidade de Brasília, Brasília, 2019.

SIQUEIRA, Carlos Henrique R. de. A alegoria patriarcal: Escravidão, raça e nação nos Estados Unidos e no Brasil. 2007. Tese (Doutorado em Ciências Sociais) - Centro de Pesquisa e Pós-Graduação sobre as Américas, Universidade de Brasília, Brasília, 2007.

VELECI, Nailah Neves. Cadê Oxum no espelho constitucional? os obstáculos sócio-político-culturais para o combate às violações dos direitos dos povos e comunidades tradicionais de terreiro. 2017. Dissertação (Mestrado em Direitos Humanos) - Universidade de Brasília, Brasília, 2017.

VON MARTIUS, Karl Friedrich. Como se deve escrever a história do Brasil. Jornal do Instituto Histórico e Geográfico Brasileiro, Rio de Janeiro, n. 24, p. 401-402, jan. 1845.

WERNECK, Jurema. De ialodês e feministas: reflexões sobre a ação política das mulheres negras na América Latina e Caribe. Nouvelles Questions Féministes, Revue Internationale Francophone, v. 24, n. 2, 2005. 
Para publicar na revista Brasileira de Políticas Públicas, acesse o endereço eletrônico www.rbpp.uniceub.br

Observe as normas de publicação, para facilitar e agilizar o trabalho de edição. 